Research Article/Araştırma Makalesi

\title{
A Mobile Game Experience of Pre-service Elementary Teachers: The Fundamental Theorem of Arithmetic
}

\author{
Mustafa GÖK *1 \\ ${ }^{1}$ Yuzuncu Yil University, Faculty of Education, Van, Turkey, mustafagok@yyu.edu.tr \\ * Corresponding Author: mustafagok@yyu.edu.tr
}

\begin{tabular}{|c|c|}
\hline Article Info & Abstract \\
\hline $\begin{array}{l}6 \text { November } 2019 \\
22 \text { December } 2019\end{array}$ & $\begin{array}{l}\text { In this study, the exploration processes of pre-service elementary } \\
\text { teachers of the Fundamental Theorem of Arithmetic through a mobile } \\
\text { game designed within the framework of the Theory of Didactical } \\
\text { Situations (TDS) were examined. The case study of qualitative research } \\
\text { methods was used in the research. Research participants included } 19 \text { ( } 8 \\
\text { female and } 11 \text { male) pre-service elementary teachers who studied at the }\end{array}$ \\
\hline $\begin{array}{l}\text { Keywords: Theory of didactical } \\
\text { situations, mobile games, teaching } \\
\text { mathematics, pre-service elementary } \\
\text { teachers, fundamental theorem of } \\
\text { arithmetic }\end{array}$ & $\begin{array}{l}\text { university in the 2018-2019 academic years. Research data was recorded } \\
\text { with a video camera and a voice recorder. The analysis of the data was } \\
\text { done by descriptive analysis method. In this context, the analyses were } \\
\text { examined according to the characteristics of the stages of TDS. } \\
\text { According to the results of the study, pre-service elementary teachers }\end{array}$ \\
\hline doi) $10.18009 /$ jcer.643732 & $\begin{array}{l}\text { were able to comprehend the Fundamental Theorem of Arithmetic } \\
\text { through a mobile game in accordance with the parameters of the } \\
\text { intended environment. Therefore, this suggests that the stages of TDS } \\
\text { present an effective path in this context. }\end{array}$ \\
\hline
\end{tabular}

open access ( CrossMark CC

To cite this article: Gök, M. (2020). Sınıf öğretmeni adaylarının bir mobil oyun deneyimi: aritmetiğin temel teoremi. Journal of Computer and Education Research, 8(15), 41-74. DOI:10.18009/jcer.643732

\section{Sınıf Öğretmeni Adaylarının Bir Mobil Oyun Deneyimi: Aritmetiğin Temel Teoremi}

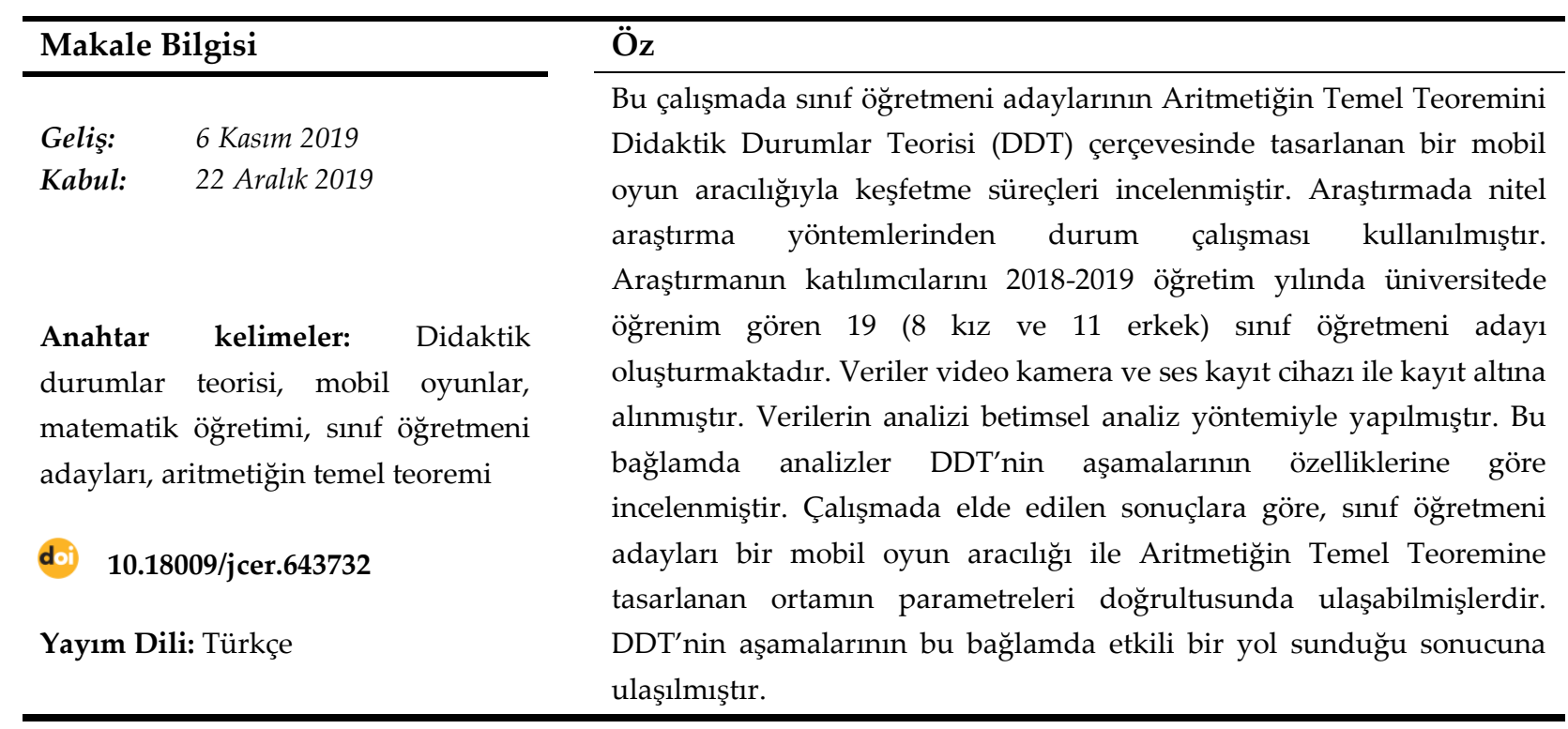




\section{Summary}

\section{A Mobile Game Experience of Pre-service Elementary Teachers: The Fundamental Theorem of Arithmetic}

\section{Introduction}

The innovative approaches used in mathematics teaching are stimulated by rapid progress in technology. However, it is noted that very few educators use technology in teaching environments (Rock \& Brumbaugh, 2013). The starting point of this study is to show pre-service elementary teachers (PETs) a way of integrating technology into education.

Kiili (2005) stated that today's generation is accustomed to technological devices because they are at the center of technology and that using only technological tools in education is not a sustainable approach. Therefore, this issue can be changed through games. For this reason, this study focused on describing the behaviors of PETs in the process of experiencing a mobile game. In this respect, the Theory of Didactic Situations was used in game design.

\section{Theory of Didactic Situations and Mathematical Game Design}

The Theory of Didactic Situations (TDS), which can be described as a game-based theory, can be used effectively for the acquisition of mathematical knowledge in a studentcentered environment (Laborde, 2007). The basic concepts of the theory are the combination of situation, milieu, and didactic.

Games designed within the framework of TDS are designed to provide an environment (milieu) where teacher interventions are largely limited and allow students to build their own knowledge so that students can access the information that is intended to be taught during the interaction process. Such cases are, in theory, called a-didactic situations (Warfield, 2014).

The a-didactic situation consists of five stages that are sequential or intertwined but happen in either way (Warfield, 2014). These stages are devolution, action, formulation, validation and institutionalization. In this study, the process of PETs exploring the Fundamental Theorem of Arithmetic through a mobile game designed within the framework 
of TDS was examined. In this context, the study searches for answers to the following questions:

- How did PETs behave at different stages of TDS during the interaction with a mobile game?

- To what extent did PETs achieve the Fundamental Theorem of Arithmetic that was hidden behind a mobile game within the framework of TDS?

What kind of awareness did the teaching process with a mobile game of mathematical knowledge within the framework of TDS create for PETs?

\section{Method}

The qualitative research method was used in this study. The model of the study can be specified as the case study. In this study, data related to a game named "bacterial colony" was investigated.

\section{The Bacterial Colony Game}

The bacterial colony game was produced in the fall semester of the 2017-2018 academic year as a result of the practices performed on PETs of a state university in the Eastern Anatolia Region (Gök, İnan, \& Akbayır, 2017).

\section{Research Participants, Data Collection Tools, and Data Analysis}

The research participants were 19 (8 female and 11 male) PETs who studied at the university in the 2018-2019 academic year. The research data was recorded with a video camera and a voice recorder. The analysis of the data was conducted through a descriptive analysis method. In this context, the analyses were constructed based on the characteristics of the stages of TDS.

\section{Results}

Teacher Behaviors during the Stages of TDS

During the devolution stage, it is seen that PETs fully understand the rules of the game. The most important indicator of this is the high winning rate in games at the beginning of the a-didactic stage. By Level 2 in the game, the winning rate had dropped dramatically. This can be explained by the incorrect transfer of the winning strategy at Level 1 to the stages at Level 2. Most hypotheses given up to game 23 were found to be rejected in the context of the game. The breaking point of this process began with the discovery of how much the bacteria in the game increased after any move. In Game 23, which can be seen as 
the first reflection of this breaking moment, the increase in bacteria after the move was taken into account and at the end of the move, the $\mathrm{K} 4$ presented a hypothesis that was confirmed by establishing a relationship between the number of bacteria and the multipliers of the requested bacterial colony. Consequently, two PETs from different groups realized the general solution by realizing the relationship between the prime multipliers of the number of bacterial colonies to be reached at each stage and the multiplication buttons in the game. It is thought that special attention should be attributed to the institutionalization stage in this study. In this context, it was observed that PETs' understanding of the Fundamental Theorem of Arithmetic was deepened on different examples.

\section{A Reflection from the Bacterial Colony Game}

In this study, some of the situations that PETs are exposed to the stages of TDS are given below:

- PETs' observation of mobile game interaction with the teacher during the devolution stage,

- Interaction between mobile game - PETs, PETs - PETs, and PETs - teacher pairs in adidactic stages,

- Teacher - PETs - mathematical knowledge interaction in the institutionalization phase.

At different stages of TDS, the fact that PETs themselves discover the Fundamental Theorem of Arithmetic through different processes through a mobile game suggests that they can get an idea of these processes. In this sense, it can be said that PETs have developed awareness about the stages here.

\section{Discussion and Conclusion}

This study examines the process of PETs' discovering the Fundamental Theorem of Arithmetic through a mobile game, and it can be stated that PETs have reached the Fundamental Theorem of Arithmetic in accordance with the parameters of the intended environment. It can also be indicated that PETs' attainment of the Fundamental Theorem of Arithmetic in the design of an environment appropriate to the constructivist approach allows them to recognize many of the paradigms of the constructivist environment. It is concluded that the stages of TDS offer an effective path in this context. 


\section{Giriş}

Gelişen teknolojilerin eğitime entegrasyonunun kaçınılmaz olduğu bir çağda yaşamaktayız. Matematiksel kavramların soyut olması (Altun, 2013; Baykul, 2014) bunu daha anlamlı kılmaktadır. Bu bağlamda matematik sınıflarında hesap makinaları, akıllı tahta, bilgisayar, Web tabanlı uygulamalar gibi araçlar kullanılmaktadır (Ozel, Yetkiner \& Capraro, 2008; Van de Walle, Karp \& Bay-Williams, 2007).

Ulusal Matematik Öğretmenleri Konseyi (The National Council of Teachers of Mathematics [NCTM]) teknolojinin matematik öğretimi ve öğreniminde araç olarak kullanılabileceğini ifade etmiştir (NCTM, 1989, 2000). Teknolojinin öğretmenlerin öğretme şeklini ve matematiksel içeriği etkilediği belirtilmekle birlikte öğrencilerin öğrenmelerini geliştirdiğine işaret edilmektedir (NCTM, 2000). Teknolojinin sınıflarda kullanımının geleneksel sınıf ortamları ile karşılaştırıldığında başarı, motivasyon, tutum ve temel beceriler (tahmin ve zihinden işlem gibi) açısından öğretimde daha iyi sonuçlar elde edildiği birçok çalışmada rapor edilmiştir (Aktaş, Bulut \& Aktaş, 2018; Cop \& Kaplan, 2018; Çetin \& Mirasyedioğlu, 2019).

Teknolojinin eğitime entegrasyonu erişim ve uygulama süreci şeklinde ifade edilebilecek iki temel sorunu doğurmuştur. Bu doğrultuda gerçekleştirilen araştırmalarda teknolojiye erişim sorunu (Aşkar \& Olkun, 2005) ve teknolojinin sinıflarda kullanımı sürecinde öğretim durumlarında ne gibi değişiklikler yaratacağı (Özdener, \& Demirci, 2019; Kiili, 2005) sıklıkla tartışılmıştır. Leatham ve Barton (2017), matematik sınıflarında teknolojinin kullanımının koşulu olarak teknolojiye erişimin gerekli olduğunu ancak yeterli olmadığını kaydetmektedir. Bu bağlamda eğitim alanında gerçekleştirilen teknolojik entegrasyonu sürekli bir yakalama oyununa benzetmekte, ancak bu oyunda sınırlı sayıda öğretmenin yer aldığını vurgulamaktadır. Rock ve Brumbaugh (2013) öğretmenlerin teknolojiyi kullanmama nedenlerinin altında materyal eksikliği, süre kısıtlaması ve öğretmenlerin teknoloji kullanımında birbirini olumsuz etkilemesi gibi faktörlerin etkili olduğunu ve öğretmen adaylarında da benzer durumların gözlendiğini belirtmiştir.

Teknolojideki gelişim nesil farkının ortaya çıkmasını tetiklemekte bu da toplumsal yapıyı etkilemektedir. Toplumsal yapı ise eğitimi etkileyen önemli bir değişkendir (Yıldırım \& Demir, 2014). Bu bağlamda öğrenenler ve öğreticiler arasında da farklılık olabilmektedir. Nitekim Prensky (2001a) bu gerçeğe işaret ederek öğrenenleri dijital yerliler ve öğretenleri dijital göçmenler olarak adlandırmıştır. Buradan öğreticilerin teknolojik anlamda çağı takip 
etmekte ve teknolojinin sınıf ortamında kullanımında zorluklar yaşadıkları anlaşılmaktadır. Sınıf ortamında teknolojinin araç olarak kullanıldığı öğretim durumlarının başarılı bir şekilde yürütülebilmesi geleceğin öğretmeni pozisyonundaki öğretmen adaylarının bu yaklaşımlara ilişkin tasarım sürecine dahil olması ve teknolojinin sınıf ortamına nasıl entegre edileceğini bilmesiyle sağlanabileceği belirtilmektedir (Penuel, Roschelle \& Shechtman, 2007). Kiili (2005), günümüz neslinin teknolojinin merkezinde yer aldığından teknolojik cihazlara alışık olduğunu, sadece teknolojik araçların kullanılmasının eğitimde sürdürülebilir bir yaklaşım olmadığını belirtmiştir. Aynı yayında bu sorunun oyunlar yoluyla değiştirilebileceği belirtilmektedir. Ancak eğitsel amaçların kazandırılmasına yönelik sınıf ortamında uygun oyunlar bulmanın çok kolay olmadığı ifade edilmektedir (ArkünKocadere \& Samur, 2016). Daha da önemlisi özel bir alanın eğitimine yönelik eğitsel dijital oyun tasarlama ve ilgili alanın özelliklerini dikkate alma oyun tasarımında daha çok değişkenin işe koşulmasını gerektirmektedir. Bu bağlamda eğitsel dijital oyunlarla, oyunların eğlenceli yönlerinin belirlenen eğitim hedeflerini kazandırabilmek için uyarlanmasının (Kukul, 2013) yanı sıra ilgili alanın dinamikleri ve dijital oyun tasarlama süreçlerinin birlikte ele alınması kastedilmektedir.

Matematik dersi öğretim programında konunun ilgili yerlerinde oyunların kullanılması önerilmektedir (Milli Eğitim Bakanlığı [MEB], 2018a). Diğer taraftan rastgele bir oyun deneyiminin eğitsel amaçlara gerektiği ölçüde hizmet etmeyeceği belirtilebilir. Bu bağlamda Artym, Carbonaro ve Boechler (2016), öğretmen adaylarının çok oyun oynamasının oyun tasarım öğelerini bildiğini göstermediğini tespit etmiştir. Bu tür tasarımların nasıl yapıldığını bilme ve bunları sınıf ortamında uygulama noktasında öğretmenlerin yalnız bırakıldı ğı ifade edilebilir.

Eğitimde teknolojinin kullanımını sürdürülebilir bir zemine oturtulmasında önemli bir rolü bulunan oyun nedir? Teknolojik entegrasyon sonrasında oyun hangi bağlamlarda eğitsel amaçlı kullanılmaktadır? Matematik eğitiminde teknoloji ve oyun nasıl ilişkilendirilmiştir? Bu sorular bağlamında çalışmaya derinlik katılacaktır.

Oyunun tanımı üzerine araştırmacıların fikir birliğinin olmadığı belirtilebilir. ArkünKocadere ve Samur (2016) oyunu, bir amacı gerçekleştirmek için belirli kurallar bağlamında mekanik bir süreçle (örneğin zıplama, taş atma gibi) mücadele ederek bir sonuca ulaşmayı gerektiren eğlenceli etkinlik olarak tanımlamışlardır. Diğer bir tanımda oyun, oyuncunun belli bir görevi bir dizi kurala uygun bir şekilde gerçekleştirdiği karmaşık bir sistem olarak 
belirtilmiştir (Domínguez, vd., 2013). Bu tanımlarda ortak öğeler oyunda bir amacın olduğu ve bu amacın bir kurallar kümesiyle sınırlandırılarak çözüm arandığıdır. Aslında matematik de benzer yaklaşımlar kullanmaktadır. Örneğin bir denklemin çözümü $(x+2=5$ denkleminin reel sayılarda çözümü gibi) belirli aksiyomlar ve özellikler bağlamında gerçekleştirilmektedir. Bu gerçeğe dikkat çeken Bishop (1991), çoğu matematikçi için oyunların kurallara dayalı davranışlar olmaları nedeniyle matematik yapmakla eşdeğer olduğunu ifade etmiştir.

Teknolojinin eğitime entegrasyonu bağlamında oyunun kullanıldığı yaklaşımlardan oyun temelli öğrenme ve oyunlaştırma dikkat çekmektedir. Oyun temelli öğrenme eğitim hedeflerinin öğrencilere oyun vasıtasıyla kazandırılmasıdır (Kim, Park \& Baek, 2009). Diğer bir tanımda oyun temelli öğrenme, dijital oyunların eğlendirici gücünün eğitim amaçlı kullanılması şeklinde açıklanmıştır (Prensky, 2001b). Burada özellikle oyunun öğrenme yerine geçtiği vurgulanmaktadır. Oyunlaştırma ise oyun öğelerinin (puan, rozet, seviye gibi) oyun dışı sistemlere uygulanması olarak tanımlanmaktadır (Deterding, vd., 2011). Bu sayede oyuncuların söz konusu oyun dışı sistemle ilgili ortama bağlanmaları ya da bu ortamda deneyimlerini arttırmaları sağlanmaktadır.

Matematik eğitiminde farklı düzeylerde (ilköğretim, lise ve üniversite) ve değişik şekillerde teknolojinin (bilgisayar oyunu, mobil oyun, Web 2.0 gibi) oyun tabanlı öğrenmeler çerçevesinde öğretim durumlarında kullanıldı̆̆ı birçok araştırma bulunmaktadır. Durgut (2016), eğitsel oyunların meslek yüksekokulu öğrencilerinin matematik dersindeki başarı ve motivasyonlarını artırdığını belirtmiştir. Çubukluöz (2019), Scratch programı aracılığıyla tasarlanan ortamların ortaokul 6. sınıf öğrencilerinin güçlük yaşadıkları konularda (asal çarpanlarına ayırma, üslü ifadeler gibi) çoğunlukla pozitif gelişmeler gösterdiklerini ifade etmiştir. Genç, Issı ve Yıldız (2017) nokta belirleme tekniğine dayalı bir mobil oyun uygulamasının özellikle özel eğitime ihtiyaç duyan bireylerin matematik öğretiminde etkili olarak kullanılabileceğini iddia etmektedir. Aktaş, Bulut ve Aktaş (2018), ortaokul 6. sınıf öğrencilerine dört işlem becerisinin kazandırılmasına yönelik mobil destekli teknolojilerle verilen eğitimin, öğrencilerin tahmin ve zihinsel işlem becerisi olumlu yönde etkilediğini tespit etmiştir. Faghihi ve diğerleri (2014) deneysel bir çalışmada, üniversite öğrencilerine “MathDungeon" oyunu ile verilen eğitimin, hiçbir eğitim verilmeyen ve en yaygın öğretim programına göre verilen eğitimle karşılaştırıldığında, ikinci dereceden denklemlerin 
köklerini belirleme açısından, teknoloji destekli oyun temelli yaklaşım lehine anlamlı farklılık gözlendiğini belirtmiştir.

$\mathrm{Bu}$ gün ve gelecekte öğretmen olmayı düşünen bireylerin teknolojinin eğitime entegre edilmesiyle ilgili süreçlerin farkında olması, bu süreçlerin sınıf ortamında nasıl kullanılacağını bilmesi ve bu tür deneyimleri bizatihi deneyimlemesi buradaki süreçlerin içselleştirilmesinde büyük önem taşımaktadır. Bu yüzden bu çalışmada mobil bir oyunu sınıf öğretmeni adaylarının deneyimleme süreçlerinde ortaya çıkan davranışlarının betimlenmesine odaklanılmıştır. Bu doğrultuda oyun tasarımında Didaktik Durumlar Teorisinden yararlanılmıştır.

\section{Didaktik Durumlar Teorisi ve Matematiksel Oyun Tasarmı}

Oyun temelli bir teori olarak belirtilebilecek Didaktik Durumlar Teorisi (DDT) matematiksel bilginin öğrenci merkezli bir ortamda edinimine yönelik etkin bir şekilde kullanılabilmektedir (Laborde, 2007). Teorinin temel kavramlarından biri durum kavramıdır. Matematiksel bir durum, bir ya da birkaç öğrencinin matematiksel bir bilgiyi kullanması ve öğrenmesini gerektiren ilgili şartlar ya da bu bağlamda uygun bir şekilde organize edilen bir proje olarak belirtilmektedir (Warfield, 2014).

Teorideki diğer önemli bileşen ortam (milieu) kavramıdır. Ortam, belirli bir alan, öğretmen, materyaller, diğer öğrencilerin varlığı ya da yokluğu da dahil olacak şekilde öğrenciyi çevreleyen ilgili bütün özelliklerdir (Warfield, 2014). Ortam öğretimsel bir amaç doğrultusunda özenle tasarlanmaktadır. Bu doğrultuda teoride oyunlar etkili bir şekilde kullanılmaktadır. DDT çerçevesinde tasarlanan oyunlar öğretmenin müdahalelerinin büyük ölçüde sınırlandırıldığı ve öğrencilerin kendi bilgilerini inşa edebilmelerine olanak sağlayan bir ortam (milieu) ile öğrencilerin etkileşim sürecinde öğretilmesi hedeflenen bilgiye ulaşabilecekleri durumlar şeklinde tasarlanmaktadır. Bu tür durumlar teoride adidaktik durumlar olarak adlandırılmaktadır (Warfield, 2014; Brousseau, 1997).

Adidaktik bir durum sıralı ya da iç içe geçen ama bir şekilde gerçekleşen beş aşamadan oluşmaktadır (Warfield, 2014). Bunlardan birincisi sorumluluk aktarma aşamasıdır. Sorumluluk aktarma aşamasında, öğretmenin beklentileri önemsenmeksizin anlamlı öğrenmelerin başarılabilmesi için öğrencilerin oyunun sorumluluğunu üzerine alması gereken aşamadır (Ligozat \& Schubauer-Leoni, 2010). İkinci aşama olan eylem aşamasında, öğrencilerin ortam ile etkileşim halinde olduğu ve ondan bir takım anlamlar 
edindikleri aşamadır (Warfield, 2014). Bu aşamada öğrenciler oyunda örtük bazı kazandıran stratejilere ulaşmaktadır. Bir sonraki aşama olan ifade etme aşamasında, bu örtük stratejiler açı fikirler ve hipotezler olarak sınıf ile paylaşılmaktadır. Dördüncü aşama olan doğrulama aşamasında ifade etme aşamasında ileri sürülen fikirler tartışılarak bir başkasına açılanmakta ve doğrulanmaya (onay ya da çürütme) çalışılmaktadır. Yukarıda bahsedilen aşamalarda oyunda gizlenen hedef bilgiye sınıfın ulaşacağı varsayılmaktadır. Son aşama olan kurumsallaştırmada, sınıfın geliştirdiği fikirleri öğretmen oyun bağlamından çıkararak ve herkesin anlayacağı şekilde yeniden organize ederek, matematiksel bir derinlik kazandirmaktadir.

Teorinin diğer bir bileşeni de didaktik sözleşmedir. Didaktik sözleşme kavramı, öğretim sürecinde öğretmen ve öğrenci arasındaki ilişkileri düzenleyen kuralların tümüdür (Brousseau, Sarrazy \& Novotná, 2014). Bu sözleşmenin amacı, bir öğretim durumunda sözleşmenin taraflarının eylem ve tepkilerini ayarlamak olarak belirtilebilir. Bu sözleşmenin somut bir sözleşme olmaktan ziyade eğitimde genellikle örtük olarak var olduğu kabul edilmektedir. Bu sözleşmenin varlığı öğretmen ya da öğrencilerin didaktik sözleşmeyi bozmaya yönelik girişimleri olduğunda gün yüzüne çıkmaktadır (Erdoğan, 2016). Didaktik sözleşmeyi bozmaya yönelik girişimin özellikle sorumluluk aktarma ve kurumsallaştırma aşamasında olabileceği belirtilmektedir (Brousseau, Sarrazy \& Novotná, 2014).

Matematik eğitiminde DDT'nin teorik çerçeve olarak yer aldığı ve teknolojik araçların kullanıldığı çalışmaların sınırlı sayıda olduğu görülmektedir. Samaniego ve Barrera (1999), TI-92 grafik hesap makinesi yardımıyla bazı problemlerin on ikinci sınıf öğrencilerine adidaktik bir ortamda çözülebileceğini ileri sürmüşlerdir. Ancak çalışmada problem çözümlerinin ve dersin uygulamasının nasıl ortaya çıktığına ilişkin herhangi bir açıklama verilmemiştir. Cahyono (2018), sınıf dışı öğretim durumları kapsamında DDT'yi de içeren bir kuramsal çerçevede mobil teknolojilerin kullanıldığ1 87 görevden oluşan matematik parkurları tasarlamıştır. Burada ortaokul öğrencilerine gerçek yaşamla bağlantılı, işbirliğini gerektiren, farklı bakış açıları sunan, belirli bir sürede gerçekleştirilen otantik durumlar oluşturulmasıyla matematiksel görevleri (günlük yaşamda karşılaşılabilecek geometrik şekillere ilişkin çevre, alan, hacim bulma gibi görevler) çözme durumlarını araştırmıştır. Araştırma sonuçlarına göre, aktivitelere katılan öğrencilerin matematik öğrenmeye yönelik tutumlarında ve motivasyonlarında olumlu yönde gelişim sağlandığı belirtilmiştir. Selman ve Tapan-Broutin (2018), yedinci sınıf öğrencilerine DDT çerçevesinde Cabri-Geometri 
yazılımı kullanılarak simetri dönüşümü içeren bir kara kutu etkinliğini deneyimleme sürecini incelemiştir. Öğrencilerin davranışları DDT'nin aşamaları bağlamında analiz edilmiştir. Çalışmanın sonuçları, DDT'nin simetri dönüşümünün Cabri-Geometri kullanılarak öğretiminde etkili bir yol olduğunu iddia etmektedir. Teknolojinin öğrenme durumlarında kullanılmasının adidaktik öğrenme ortamlarının daha etkili ve kavramsal bir şekilde kullanılmasına yol açtığı belirtilebilir. Nitekim teknolojik destekten yoksun olarak tasarlanan ve DDT'nin kullanıldığı diğer bir çalışmada, öğretmen adaylarının bir geometrik örüntüdeki formülü keşfetmesi sürecinde deneysel örneklere dayanan bir varsayıma bağlı ortaya atılan formül ile geometrik örüntünün yapısal ilişkilerinin kullanılması sonucu elde edilen formül arasındaki ayırımı öğretmen adaylarının algılamakta güçlük yaşadıkları görülmüştür (Måsøval, 2009). Burada dikkat çeken husus, teknolojiden yararlanıldığında bu zorluğun giderilebileceği olarak açılanabilir. Nitekim birçok çalışmada teknoloji kullanıldığında öğrencilerin öğretilmesi hedeflenen matematiksel bilgiyi yapılandırabildikleri vurgulanmıştır (Selman \& Tapan-Broutin, 2018). Bu öğrenme durumunun ortaya çıkmasında teknolojinin etkisi yadsınamaz. Diğer taraftan eğitim sürecinde sadece teknolojinin sürdürülebilir bir yaklaşım olmadığı ve bununla birlikte oyun öğesinin bu sürece dahil edilmesi gerektiği belirtilmektedir (Kiili, 2005).

Literatürde matematiksel bir bilginin DDT'nin teorik çerçevesinde mobil teknolojiler ile bir oyun bağlamı kurularak tanıtıldığı ya da öğretildiği bir çalışmaya rastlanmamıştır. Bu bağlamda bu çalışma özgün bir nitelik taşımakta ve literatüre yeni bir nefes katmaktadır. Bu çalışmada öğretmen adaylarının Aritmetiğin Temel Teoremini DDT çerçevesinde bir mobil oyun ile keşfetme süreci incelenmiştir. Bu doğrultuda aşağıdaki sorulara yanıt aranmaktadır:

- Öğretmen adayları mobil oyun ile etkileşim sürecinde DDT'nin farklı aşamalarında nasıl davranmışlardır?

- Öğretmen adayları, DDT çerçevesinde geliştirilen mobil oyunun arkasına gizlenen Aritmetiğin Temel Teoremine ne ölçüde ulaşabilmiştir?

DDT çerçevesinde matematiksel bir bilginin mobil bir oyun ile öğretim süreci öğretmen adaylarında ne tür farkındalıklar yaratmış olabilir?

\section{Yöntem}

$\mathrm{Bu}$ çalışmada nitel araştırma yöntemi kullanılmıştır. Çalışmanın modeli durum çalışması olarak belirtilebilir. Durum çalışmaları, sınırlı bir sistemin derinlemesine 
betimlenmesi ve incelenmesi olarak tanımlamıştır (Merriam, 2013). Bu çalışmada, sınıf öğretmeni adaylarının DDT’nin argümanları kullanılarak oluşturulan eğitsel bir mobil oyunu deneyimleme süreci incelenmiştir. Mobil oyun sınıf öğretmeni adaylarına uygulanarak oyunlaştırma süreçleri ile ilgili farkındalık yaratılmak istenmektedir. Bu çalışmada bakteri kolonisi olarak adlandırılan bir oyuna ilişkin veriler incelenmiştir.

\section{Bakteri Kolonisi Oyunu}

Bakteri kolonisi oyunu, 2017-2018 öğretim yılı güz yarıyılında Doğu Anadolu'da bir devlet üniversitesinin sınıf öğretmeni adayları üzerinde gerçekleştirilen uygulamalar sonucunda üretilmiştir (Gök, İnan \& Akbayır, 2017).

\section{Oyun Tasarımı ve Kodlanması}

Oyun tasarımı, oyunda oluşturulacak ekranların karakalem çalışması ile başlanmıştır. Arka plan resimleri ve ikonlar için genellikle Adobe Illustrator kullanılmıştır. Kodlama kısmı Android Studio ortamında Java dili kullanılarak gerçekleştirilmiştir. Oyunları kodlarken Android sürümü olarak 2.1 kullanılmıştır.

\section{Bakteri Kolonisi Oyununun Kuralları ve Oyunun Tanıtılması}

Bakteri kolonisi oyunu temelde tek kişiyle oynanmaktadır. Ancak bu çalışmada oyunlaştırma süreçleri kullanılarak bir yarışma bağlamında sunulmuştur. Burada oyun iki büyük grubun oyunda kazandıran strateji ya da stratejileri ortaya çıkarmaya yönelik mücadelesi bağlamında uygulanmıştır. Bunun için öğretmen adayları üç gruba ayrılmıştır. Sonra oyunu her gruptan bir kişi sırayla akıllı tahta üzerinden oynamış ve oyunu kazanan oyuncuların gruplarına 1 puan kazandıracağı açıklanmıştır. Böylece oyundaki puanlamadan farklı bir puanlama daha sürece dahil edilerek oyun oyunlaştırılmaya çalışılmıştır. Oyunun akıllı tahtada oynanması motivasyonu ve etkileşimi arttırmaktadır. Bununla birlikte hipotez verme ve doğru hipotezin de puanlandırılması rozet olarak değerlendirilebilir. Ayrıca DDT'nin aşamalarında öğretmen adaylarının rolleri değişmektedir. Örneğin doğrulama aşamasında bazı oyunlar oyunu keşfederken, bazıları karşı takımın hipotezlerini inceleyerek çürütmeye yönelik bir role bürünmektedir. Oyunun seviye 1'den seviye 3'e doğru zorlaşması meydan okumayı canlı tutmaktadır.

Oyun tasarımı sürecinde Prensky (2001b)'nin önerdiği 6 kriter kullanılmıştır. Bunlar: 1. Kurallar, 2. Amaçlar ve hedefler, 3. Sonuçlar ve geri bildirim, 4. Çatışma, rekabet, meydan 
okuma ve muhalefet, 5. Etkileşim, 6. Temsil veya hikaye şeklinde belirtilmiştir. Aşağıda bu süreçler oyun bağlamında sunulmuştur.

Oyunun tanıtımı ve kuralları: Oyun ikonuna tıklandıktan sonra üç seviye seçeneği ile karşılaşılmaktadır. Bu seviyeler seviye 1'den seviye 3'e doğru kolaydan zora olacak şekilde dizayn edilmiştir. Seviye 1'de ilk oyun ekranında ve sonraki her oyunda, başlangıçta 1 adet bakteri oyun alanında sol üst köşede mavi renkte konumlandırılmıştır. Ekrana toplam 100 adet bakteri sığacak biçimde ekran organize edilmiştir. Satır ve sütunda 1, 2, 4 ve 6 sayılarının yer aldığı butonlar bulunmaktadır (Şekil 1). Bu butonlara basıldığında bakteri sayısı belli bir kural doğrultusunda çoğaltılmaktadır. Ancak her çoğaltma işleminde yeni bakteriler farklı bir renkte olacak şekilde türetilmektedir. Üstteki butonlar çoğaltma işlemini sağa doğru (Sağ Yön Çoğaltma Butonları: S) ve ekranın yanındaki butonlar çoğaltma işlemini aşağı doğru (Aşağı Yön Çoğaltma Butonları: A) gerçekleştirmektedir. Çoğaltma işlemi herhangi bir andaki bakteri ya da bakterilerin tamamı üzerinden gerçekleşmektedir. Her oyunda ekranın üst kısmında ulaşılmak istenen bakteri kolonisinin sayısı verilmiştir.
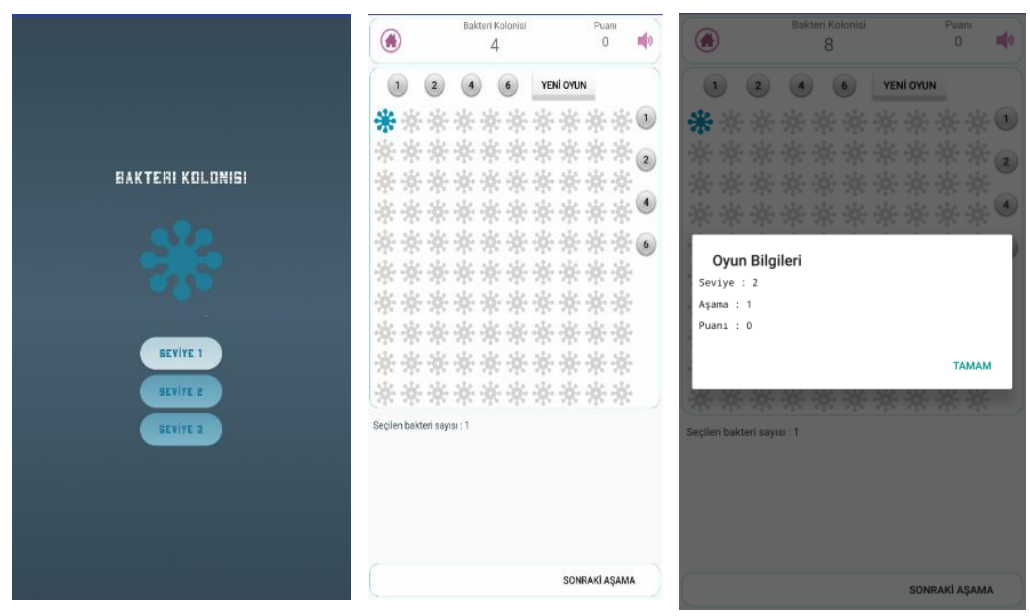

Şekil 1. Bakteri kolonisi oyununun ikonu, seviyeleri ve başlangıcı

Şekil 1'de bakteri kolonisi oyununun ikonu, seviyeleri (seviye 1, seviye 2 ve seviye 3) ve ilk oyun başlangıcı verilmiştir. Oyun ekranının üst kısmında ulaşılması istenen bakteri sayısı ve puan bulunmaktadır. Oyun alanının hemen üstünde sağ yön çoğaltma butonları (1, 2, 4 ve 6) ile yeni oyun butonu yer almaktadır. Oyun alanının yanında aşağı yön çoğaltma butonları verilmiştir. Oyun alanının hemen altında herhangi bir anda oyun alanında bulunan bakteri sayısı görülmektedir. Ayrıca ekranın sol üst köşesinde ana menü, sağ üst köşede seçim yapıldığını bildiren seslendirme ve sağ alt köşesinde sonraki aşamaya geçiş butonu konumlandırılmıştır. 
Amaçlar ve hedefler: Oyunu kazanmak için, satır ve sütunlarda verilen butonlar vasıtasıyla 1 bakteriden ekranın üst kısmında yazılı olan sayı kadar bakteriyi, ekranda oyun alanda çoğaltmak gerekmektedir. Ayrıca oyun rastgele tasarlanmamıştır. Oyunun içine bir matematiksel bilgi gizlenmiştir. Bu bilginin oyun sürecinde keşfedileceği iddia edilmektedir. Bu doğrultuda bu oyunda nihai amaç, Aritmetiğin Temel Teoreminin keşfedilmesidir.

Sonuçlar ve geri bildirim: Bu oyunda ekranda oyun alanında satır ve sütunlara 10'dan fazla bakteri dizmek mümkün değildir. Böyle bir durum gerçekleşirse oyun "Lütfen başka bir sayı seçiniz. Sütun/Satır uygun değil”' uyarısı vermektedir. Her oyunda ilk bakteri ekranda sol üst kısımda mavi renkte konumlandırılmıştır. Sağ yön çoğaltma butonlarına basıldığında bu bakterisinin sağında yeni bakteriler oluşmaktadır.

- Eğer ilk konumdan sonra Sağ Yön Çoğaltma Butonu 1'e (S1) basılırsa ** şeklinde,

- Eğer ilk konumdan sonra Sağ Yön Çoğaltma Butonu 2'ye (S2) basılırsa *** şeklinde,

- Eğer ilk konumdan sonra Sağ Yön Çoğaltma Butonu 4'e (S4) basılırsa ***** şeklinde,

- Eğer ilk konumdan sonra Sağ Yön Çoğaltma Butonu 6'ya (S6) basilırsa ******* şeklinde bir çoğalma meydana gelmektedir.

- Her çoğaltma işlemi farklı renkte gerçekleştirilmektedir. Bu bağlamda başlangıç her zaman mavi olacak şekilde renk sıralaması mavi, mor, yeşil, turuncu, siyah, kırmızı ve sarı şeklindedir. Örneğin ilk konumdan sonra sağ yön çoğaltma butonlarından 2'ye 2 kez basıldığında oyun ekranında ******** görüntüsü ortaya çıkmaktadır. Benzer durum aşağı çoğaltma butonlarına basıldığında bakteri kolonisinin dizimi aynı renk ve sayıda ancak yukarıdan aşağı doğru konumlandırılmaktadır. Şekil 2'de bu oyunda 6 adet bakteri kolonisine ulaşabilmenin bazı değişik kombinasyonları verilmiştir. 


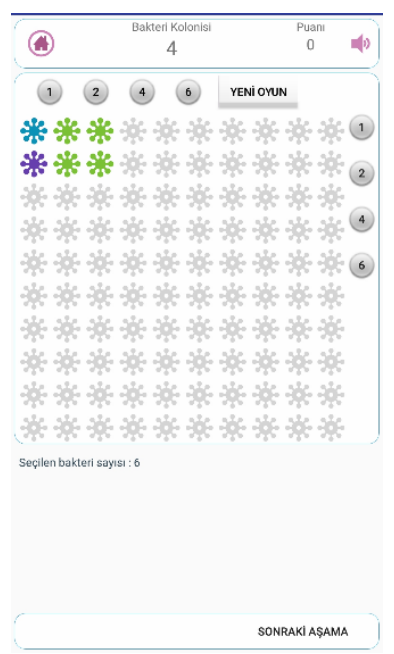

$\mathrm{A} 1, \mathrm{~S} 2$

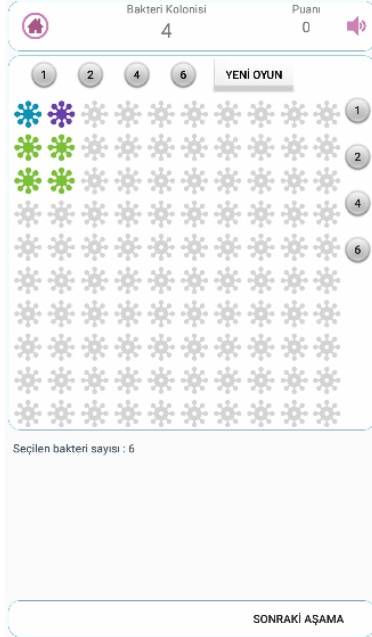

$\mathrm{S} 1, \mathrm{~A} 2$
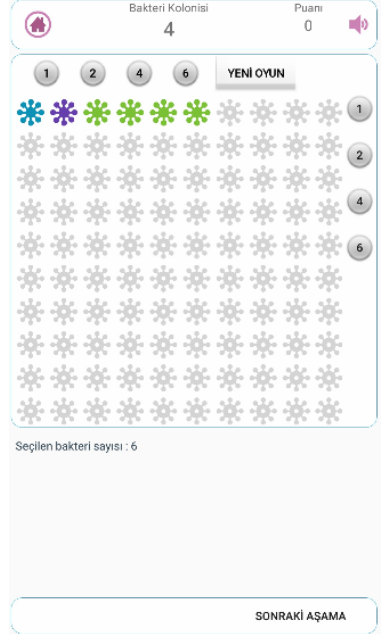

$\mathrm{S} 1, \mathrm{~S} 2$

Şekil 2. Bakteri kolonisi oyununda 6 bakteriye ulaşmanın bazı değişik kombinasyonları

Şekil 2'de 6 bakteri oluşturmanın altı farklı yolundan üçü verilmiştir. Kolonideki bakterilerin sayısına ulaşıldığında oyun kazanılmaktadır. Kolonideki bakteri sayısına ulaşıldığında ekranda "Tebrikler" şeklinde bir yazı çıkmaktadır. Bu oyunda butonlar mevcut bakteri sayısını sadece arttırmaktadır. Bu doğrultuda bakteri sayısının azalması söz konusu değildir. Eğer bulunması hedeflenen bakteri sayısı oyun sürecinde aşılmış ise oyunun kaybedildiği anlaşılmaktadır. Şekil 2' de verilen bütün oyunların kaybedildiği görülmektedir. Çatışma, rekabet, meydan okuma ve muhalefet: Oyun kolaydan zora üç seviyeden oluşmaktadır. Seviye 1 (Basit): Bu seviyede ulaşılması gereken bakteri kolonisi sayıları \{4, 6, 9, 10, 14, 15, 21, 25, 35, 49\} şeklinde oluşturulmuştur. Kümedeki her bir sayı oyunda geçilmesi gereken bir aşamadır. Dolayısıyla bu seviyede 10 aşama bulunmaktadır. Bu sayılar rastgele oluşturulmamıştır. Dikkat edilirse her bir sayının sadece iki asal çarpanı (asallar aynı olabilir) bulunmaktadır. Seviye 2 (Orta): Bu seviyede ulaşılması gereken bakteri kolonisi sayıları $\{8,12,18,20,27,28,45,50,63\}$ şeklinde oluşturulmuştur. Benzer şekilde bu seviyede 9 aşama bulunmaktadır. Bu aşamalarda kullanılan sayılar üç asal çarpana (aynı olabilir) sahiptir. Seviye 3 (Zor): Bu seviyede ulaşılması gereken bakteri kolonisi sayıları \{16, 24, 40, 54, 56, 81, 100\} şeklindedir. Bu sevide 7 aşama bulunmaktadır. Bu aşamalarda kullanılan sayılar dört asal çarpana (farklı olmak koşulu yok) sahiptir. Oyunlar seviyelere göre puanlanmaktadır. Seviye 1'deki her oyun 2 puan, seviye 2'deki her oyun 3 puan ve seviye 3'deki her oyun 4 puan değerindedir.

Oyunun oyunlaştırılarak bir yarışma bağlamında sunulmasının da gruplar arası mücadeleyi daha aktif bir konuma taşıyacağı düşünülmektedir. Bu bağlamda her bir aşama 
sırayla gruplardan bir kişi tarafından akıllı tahtada çözülmeye çalışılmıştır. Bir aşamayı kazanan kişi grubuna 1 puan, hipotez sunan ve hipotezi onaylanan grup 2 puan, hipotezi çürüten grup 3 puan ve oyunda daima kazandıran stratejiyi bulan gruba 5 puan verileceği açıklanmıştır (oyundaki puanlamadan farklı bir puanlama).

Etkileşim: Bu oyunda etkileşimin birçok yönü olmakla birlikte, etkileşimin her bir yönü farklı bir anlama sahiptir. Öğrenci-öğrenci etkileşiminde rekabet hissi ile karşı grubun argümanları çürütülmeye çalışılmakta ve kendi grubunun oyunda kazandıran stratejisine yönelik katkı verilmeye çalışılmaktadır. Ayrıca oyun sürecinde öğrencilerin oyundan edindikleri anlamlar doğrultusunda yeni bilgiler grup içi ya da gruplar arası tartışmalarda açık bir şekilde ortaya çıkarılmaya çalışılmaktadır. Bu sayede öğrenciler oyundaki amaçları gerçekleştirmeye çalışmaktadır. Oyun-öğretmen etkileşimi genel olarak oyunun öğrencilere açıklanmasını içermektedir. Öğretmen-öğrenci etkileşiminde ise öğretmen rehber konumunda olup, ortamı organize etmekte ve çözüme yönelik olmayan ipuçları vermektedir. Öğrenci ise oyunun kuralları doğrultusunda oyuna çözüm bulmaya çalışmaktadır. Öğrenmenin sorumluluğunu üstlenmesi gerekmektedir. $\mathrm{Bu}$ süreçte öğretmenin beklentilerinden ziyade oyunda amaçları kendi fikirlerini yansıtmak suretiyle ortaya koyması beklenmektedir.

Temsil veya hikaye: Aritmetiğin Temel Teoreminin içerisine saklandığı bu mobil oyun, günlük yaşamdan bir bağlam verilerek öğrencilere sunulmuştur. Bu doğrultuda oyunda bir bakterinin belli sınırlılıklar ve koşullar altında çoğalarak bakteri kolonisi oluşturma süreci incelenmiştir.

\section{Araştırmanın Katılımcıları}

Araştırmanın katılımcılarını 2018-2019 öğretim yılında Doğu Anadolu bölgesinde bir devlet üniversitesinde öğrenim gören 19 (8 kı ve 11 erkek) sinıf öğretmeni adayı oluşturmaktadır. Katılımcılar amaçlı örnekleme yöntemiyle belirlenmiştir. Amaçlı örnekleme yapılmasında araştırma konusuyla ilgili zengin veri elde etmek hedeflenmektedir (Yıldırım \& Şimşek, 2016). Bu doğrultuda katılımcılar matematik öğretimi I dersinin gereklilikleri kapsamında gönüllü olarak oyun sürecinde yer almak isteyen sınıf öğretmeni adaylarıdır.

Öğretmen adayları üç gruba ayrılarak uygulama gerçekleştirilmiştir. Oyun grupların bilgisayara karşı oynadıkları bir yarışma bağlamıyla uygulanmıştır. Gruplardan herhangi biriyle başlanmış ve bu gruptan bir kişi akıllı tahtada oyunu bilgisayara karşı oynamıştır. Daha sonra sırayla diğer gruplardan bir öğrenci benzer şekilde akıllı tahtada oyunu 
bilgisayara karşı oynamıştır. Oyun sürecinde kazanma, hipotez sunma, hipotez çürütme ve oyunda daima kazandıran strateji ortaya koyma ayrı ayrı puanlanmaktadır. Katılımcılar bulgularda; grup 1'e 3 ile bölümünden kalanı 1 olan sayılar K1, K4,.., K16 ve grup 2'ye 3 ile bölümünden 2 kalanı olan sayılar K2, K5,.., K20 ve grup 3'e 3 ile tam bölünen sayılar K3, $\mathrm{K} 6, \ldots . ., \mathrm{K} 18$ verilerek sunulmuştur. Bu doğrultuda grup 1 altı kişi, grup 2 yedi kişi ve grup 3 altı kişidir. Uygulama araştırmacı tarafından gerçekleştirilmiş ve bu kişi bulgularda Öğretmen (Ö) olarak kodlanmıştır.

\section{Oyunun Uygulaması ve Verilerin Toplanması}

Bakteri kolonisi oyunu 2 sınıf öğretmeni adayına uygulanarak pilot çalışması yapılmıştır. Pilot uygulama 59 dakika sürmüştür. Daha sonra 16 (6 kız ve 10 erkek) sınıf öğretmeni adayına sınıf ortamında uygulanmıştır. İkinci pilot olarak ifade edilebilecek bu uygulama 45 dakika sürmüştür. Bu oyun akıllı tahtada gerçekleştirilmiştir. Ancak oyun teknik bir arıza nedeniyle 4-5 oyun oynandıktan sonra kendi kendine kapanmıştır. Pilot uygulama sonrası oyuncunun seçimlerinin yapıldığını belirten ses efekti eklenmiş ve kazanılan oyun sonrasında doğrudan diğer oyuna geçmek yerine "sonraki aşama" şeklinde bir buton eklenmiştir. Diğer aşamaya ancak bu buton sayesinde geçilebilecektir. Bu sayede oyuncunun gerçekleştirdiği oyunu tartışma olanağı sağlanmaktadır. Ayrıca akıllı tahtada sürekli oyunun kapanma sorunu giderilmiştir.

Asıl uygulama 48 dakika sürmüştür. Asıl uygulama cep telefonu yerine sinıf ortamında oyunun daha kolay uygulanabilmesi ve tartışılabilmesi için akıllı tahta üzerinden gerçekleştirilmiştir. Asıl uygulamaların verileri etkinliğin video kamera ve ses kayıt cihazı ile kayıt altına alınması yoluyla toplanmıştır. Bu veriler kayıtların tekrar tekrar dinleme metoduyla bilgisayar ortamına aktarılmıştır.

\section{Verilerin Analizi}

Verilerin analizi betimsel analiz yöntemiyle yapılmıştır. Bu doğrultuda DDT’nin farklı aşamalarında ilgili aşamanın karakteristik özelliklerini gösteren doğrudan alıntılara yer verilmiştir. DDT'nin aşamalarına ilişkin özellikler öğretmen, öğrenci ve matematiksel bilgi bağlamında Tablo 1'de verilmiştir. 
Tablo 1. DDT'nin farklı aşamalarının özellikleri

\begin{tabular}{llll}
\hline Aşamalar & Bilgi & Öğretmen & Öğrenci \\
\hline $\begin{array}{l}\text { Sorumluluk } \\
\text { Aktarma }\end{array}$ & Oyun içinde gizli bilgi & $\begin{array}{l}\text { Oyunun } \\
\text { açılama }\end{array}$ \\
\hline Eylem & Örtük modeller & Ortamı organize etme & Oyun ile mücadele \\
\hline İfade Etme & Açık modeller & Ortamı organize etme & $\begin{array}{l}\text { Hipotez, fikir ve argüman } \\
\text { üretme }\end{array}$ \\
\hline Doğrulama & $\begin{array}{l}\text { Oyun bağlamında bilginin } \\
\text { bir formuna ulaşma }\end{array}$ & Ortamı organize etme & Açıklama, kanıt yapma \\
\hline Kurumsallaştırma & $\begin{array}{l}\text { Bilgiye } \\
\text { derinlik katma matematiksel }\end{array}$ & $\begin{array}{l}\text { Oyunda gizlenen } \\
\text { bilgiyi açıklama }\end{array}$ & $\begin{array}{l}\text { Matematiksel bilgi ile oyun } \\
\text { arasındaki ilişkileri anlama }\end{array}$ \\
\hline
\end{tabular}

Tablo 1'de görüleceği üzere, sorumluluk aktarma aşamasında öğretmen aktif bir rol üstlenerek etkinliğin nasıl yürütüleceği (grupları oluşturma, dönütlerinin niteliği, puanlama, gibi), oyunun amacı ve kurallarını açıklaması gerekmektedir. Bu aşamada öğretmen oyunun katılımcılar tarafından anlaşılmasını sağlayacak durumlara yer vermelidir. Eylem aşamasında sınıf öğretmeni adaylarının oyunla etkileşime girmeleri gerekmekte ve kazandıran strateji olduğunu düşündükleri bazı informel modeller geliştirmeleri beklenmektedir. Bu modeller grup içinde tartışıldıktan sonra genellenerek grupların hipotezlerine dönüşmektedir. Doğrulama aşamasında bu hipotezler büyük sınıf tartışmalarında oyun bağlamında doğrulanmaktadır. Bu süreçte sınıfın bilgisi doğrulanan hipotezlerle sürekli revize edilmektedir. Bu sayede hedef bilgiye doğru oyun bağlamında ilerleme sağlanmaktadır. Sorumluluk aktarma ile kurumsallaştırma arasındaki aşamalarda sınıf öğretmeni adayları aktif ve öğretmen ortamı organize eden bir rol üstlenmektedir. Son olarak kurumsallaştırmada sınıf öğretmeni adaylarının oyun bağlamında ulaştıkları bilgi, öğretmen tarafından formel anlamda açıklanmaktadır.

Bulgular bölümünde adidaktik aşamalarda gerçekleşen oyun ve öğretmen adayları arasındaki etkileşim süreci Tablo 2'de verildiği şekilde analiz edilmiştir.

Tablo 2. Adidaktik aşamalarda öğretmen adaylarının oyun sürecine ilişkin bileşenler

\begin{tabular}{|c|c|c|c|c|c|c|}
\hline Oyun & $\begin{array}{l}\text { Oyuncu, Grup } \\
\text { ve Cinsiyet }\end{array}$ & Oyun Süreci & $\begin{array}{l}\text { Gerçekleşen } \\
\text { Bakteri Sayıs1 }\end{array}$ & $\begin{array}{l}\text { Hedeflenen } \\
\text { Bakteri sayis1 }\end{array}$ & $\begin{array}{l}\text { Oyunda } \\
\text { Kazanılan Puan }\end{array}$ & $\begin{array}{l}\text { Yarışma Bağlamında } \\
\text { Kazanma/Kaybetme }\end{array}$ \\
\hline
\end{tabular}

Tablo 2'de soldan sağa doğru şu analizlere yer verilmiştir: oyun numarası, oyuncu ve grubu, oyunun nasıl oynandığı (S: Sağ ve A: Alt, S1A4: Sağ 1 butonu ve Alt 4 butonuna basılmış), gerçekleşen bakteri sayısı (oyuncunun ulaştığı), hedeflenen bakteri sayısı (oyunda ulaşılması gereken sayı), oyunda kazanılan puan ve yarışma bağlamında kazanılan puan 
şeklinde analizler yapılmıştır. Ayrıca adidaktik aşamalarda öğretmen adaylarının verdiği hipotezler de başka bir tabloda sunulacaktır.

Araştırmanın geçerlik ve güvenirliği ile ilgili, oyun DDT ve onun temel argümanları konusunda uzman bir matematik eğitimcisi tarafından tasarlanmıştır. Tasarlama sürecinde hedef bilginin ortaya çıkmasına ilişkin DDT çerçevesinde adidaktik durumlar kapsamında sınırlılıklar ve koşullar belirlenmiştir. Asıl uygulama öncesi pilot uygulamalar yapılması, pilot uygulamada elde edilen sonuçlar doğrultusunda mobil oyunun revize edilmesi asıl uygulamada elde edilecek veriler için sağlam bir zemin oluşturduğu belirtilebilir. Verilerin toplanmasında kamera, ses kayıt cihazı kullanılması ve uygulamanın araştırmacı tarafından yapılmasıyla katılımcı gözlem yapma olanağı olması gibi durumlar verilerin toplanmasında çoklu yolların kullanıldığını göstermektedir. Ayrıca araştırmadaki süreçlerin açık ve net bir şekilde ortaya konulmasının araştırmanın güvenirliğini arttırdı̆̆ı söylenebilir.

\section{Bulgular}

$\mathrm{Bu}$ bölüm iki alt başlıktan oluşmaktadır. Birincisinde DDT'nin aşamalarında öğretmen adaylarının davranışlarına yer verilmiştir. Bu alt başlıkta araştırma sorularından ilk ikisi yanıtlanmaktadır. Diğer bölüm gerçekleştirilen etkinliğe ilişkin bir yansıtmayı içermektedir. Burada üçüncü araştırma sorusuna yanıt verilmeye çalışılmıştır.

\section{DDT'nin Aşamalarında Öğretmen Davranışları}

DDT'nin aşamaları üç alt başlıkta incelenmiştir. Bunlar: sorumluluk aktarma, adidaktik aşamalar (eylem, ifade etme ve doğrulama) ve kurumsallaştırmadır.

\section{Sorumluluk Aktarma Aşaması}

Öğretmen bakteri kolonisi oyununa ilişkin sorumluluk aktarma aşamasını aşağıdaki sözler ile başlatmıştır.

Ö: Oyunumuzun adı bakteri kolonisi, şimdi ben bir oyun oynayacă̆ım. Bundan sonrasını size bırakacağım. Burada bakın $10 x 10$ yani 100 bakteriye ulaşabilirsiniz, maksimum. Daha ötesi bu oyunda olmuyor arkadaşlar. Şu an puanım sıfır arkadaşlar.

Bu açıklamalarda öğretmenin başlangıç stratejisi olarak ifade edilebilecek bir oyun oynayacağı ve sonrasında oyun ile öğretmen adaylarını baş başa bırakacağı anlaşılmaktadır. Ayrıca oyunda bazı sınırlılıklar olduğunu (örneğin oyun alanının 10x10 şeklinde organize edilmesi) ve bazı ipuçları mekanizmaları olduğunu (puan gibi) belirtmiştir. Bu bağlamda açıklamalarını sürdürmüş ve oyunun kurallarını aşağıda verildiği şekliyle ifade etmiştir. 
Ö: Oyunu anlatıyorum. Şu 4'e ulaşmaya çalışacağız (hedeflenen bakteri sayısı). Yani diyor ki, bir tane bakteri var. Bakteriler biliyorsunuz çoğalırlar. Şunlar (butonları gösterdi) çoğaltıyor. Tabii şuradakiler yana (ya da sağa) doğru çoğaltıyor. Ben şu an 1'e bastım (S1 bastl). 1 bakteri daha geldi ve farklı bir renk oldu. Farklı bir renk oldu ki sen o çoğalmayı takip edebilesin. Mesela 4'e basarsam 2 olan bakteri sayısı, 8 tane daha çoğaldı arkadaşlar (S4 bastı). 4'e basınca bakın 2 olan bakteri 10 tane oldu. Artık oradaki çoğalmanın formülünü siz bulacaksınız. Deneme yanılma ile. Şu an şu tuşa basarsam 1'e bastım (A1'e bastı). Aynısı bakın geldi. 2'ye basarsam bakın farklı bir renkte yine çoğalma gerçekleşti. Tabi ki, amaç ne? Amaç 4 sayısına ulaşmak. Bakın ulaşamadım. Bundan sonra ulaşmam mümkün mü? Hayır. Neden? Bakın burada seçilen bakteri sayısı 60 diyor arkadaşlar. Şurada da toplam bakteri sayısın gösteriyor. Siz burada şu butonlara bastıkça çoğalmaya devam ediyorsunuz. 4 sayısını geçmişsem arkadaşlar ve butonlara bastıkça bakteri sayısı daha artacă̆ 1 için artık 4'e ulaşmam mümkün değil. Bu oyunu kaybettiğimi gösteriyor arkadaşlar. Anladınız mı? (Evet diye yantladılar) Mesela ben uygun bir örnek vereyim size. 4'e bakın ben hemen ulaşıyorum. (S1A1 bastı) ulaştım. Şurası grup 1, şurası grup 2, sizler de grup 3 olun. Oyunda kazanan 1 puan, hipotez sunup hipotezi onaylanan 2 puan, sunulan bir hipotezi çürüten 3 puan ve oyunun tamamın çözen 5 puan alıyor. Hadi başlayın.

Öğretmen seviye 1'de aşama 1 oyununu kendisi iki farklı şekilde oynamıştır. Birincisinde oyunu rastgele oynamıştır. $\mathrm{Bu}$ oyunda oyunun kurallarını, oyundaki mekanizmaları ve butonlara basıldığında oyun ekranındaki değişimi açılamıştır. Ayrıca oyundaki aşama 1 ile ilgili gerçekleştirilmesi gereken amaç ve oyunda kazanma ya da kaybetmenin nasıl gerçekleştiği belirtilmiştir. Bu tür bir yaklaşımla öğretmen adaylarının oyun ile etkileşime girdiklerinde aşamadaki amacı gerçekleştirmek için oyundan alacakları dönütlerden nasıl yararlanacakları anlatılmak istenmiştir. İkinci oyunda ise öğretmen kazanan bir oyun oynamıştır. Ancak kullandığ1 stratejiye ilişkin hiçbir açıklama yapmamıştır. Son olarak oyunun gruplar arası bir yarışma bağlamında oynanacağı belirtilmiştir. Bu yarışmada puanlamayı da açıklamıştır. Öğretmen adaylarının oyunun kurallarını tam anlamıyla anladığından emin olduktan sonra oyunu onların oynamasına izin vermiştir. Bu aşama 7 dakika sürmüştür.

\section{Eylem, İfade Etme ve Doğrulama Aşamaları}

$\mathrm{Bu}$ çalışmada adidaktik aşamaların (eylem, ifade etme ve doğrulama) birlikte verilmesi kararlaştırılmıştır. Bunun nedeni eylem aşaması ile ifade etmenin belli bir aşamadan sonra birlikte gerçekleşmesi ve benzer şekilde daha sonra bu sürece doğrulama aşamasının da dahil olmasıdır. Adidaktik aşamalarda öğretmen adayları üç gruba ayrılmıştır. Oyun akıllı tahtada oynanmaktadır. Her oyunu (seviyelerdeki her bir aşamayı) gruplardan gönüllülük esasına göre belirlenen bir öğrenci oynamıştır. Bu süreçte diğer öğrenciler oyunu izleme pozisyonu almışlardır. Öğretmen oyun sürecinde özellikle akıllı tahtada oyunu oynayan kişiye izleme pozisyonundaki öğretmen adaylarının müdahale etmemeleri gerektiği konusunda onları uyarmıştır. Bu oyunların puanlamasında iki tür puanlama yapılmıştır. Birincisi oyun ekranında kazanılan puanlardır. Burada kazanılan her 
oyun için seviye 1 'de 2 puan, seviye 2 'de 3 puan, seviye 3 'te 4 puan kazanılmaktadır. İkinci olarak yarışma bağlamında kazanılan her oyuna 1 puan verilmiştir. Tablo 3 'te oyun sürecinde adidaktik aşamalarda öğretmen adaylarının kazanma-kaybetme durumları verilmiştir.

Tablo 3. Öğretmen Adaylarının Adidaktik Aşamalarındaki Oyun Süreçleri

\begin{tabular}{|c|c|c|c|c|c|c|}
\hline Oyun & $\begin{array}{l}\text { Oyuncu, Grup } \\
\text { ve Cinsiyet }\end{array}$ & Oyun Süreci & $\begin{array}{l}\text { Gerçekleşen } \\
\text { Bakteri Sayısı } \\
\end{array}$ & $\begin{array}{l}\text { Hedeflenen } \\
\text { Bakteri sayıs1 } \\
\end{array}$ & $\begin{array}{l}\text { Oyunda } \\
\text { Kazanılan Puan }\end{array}$ & $\begin{array}{l}\text { Yarışma Bağlamında } \\
\text { Kazanma/Kaybetme }\end{array}$ \\
\hline 1 & K1-G1-K & S1A2 & 6 & 6 & 2 & 1 \\
\hline 2 & K2-G2-E & $\mathrm{A} 2 \mathrm{~S} 4$ & 12 & 9 & 0 & 0 \\
\hline 3 & K3-G3-E & S4A1 & 10 & 10 & 2 & 1 \\
\hline 4 & K4-G1-E & S4S1A1 & 20 & 15 & 0 & 0 \\
\hline 5 & K5-G2-E & S4A2 & 15 & 15 & 2 & 1 \\
\hline 6 & K6-G3-K & S4A4 & 25 & 25 & 2 & 1 \\
\hline 7 & K7-G1-K & S4A6S1 & 70 & 49 & 0 & 0 \\
\hline 8 & K8-G2-E & S4A1 & 10 & 8 & 0 & 0 \\
\hline 9 & K8-G2-E & S2A4 & 15 & 8 & 0 & 0 \\
\hline 10 & K11-G2-K & S1A1 & 4 & 4 & 2 & 1 \\
\hline 11 & K11-G2-K & $\mathrm{S} 2 \mathrm{~A} 2$ & 9 & 9 & 2 & 1 \\
\hline 12 & K11-G2-K & S4A4 & 25 & 25 & 2 & 1 \\
\hline 13 & K11-G2-K & S6A6 & 49 & 49 & 2 & 1 \\
\hline 14 & K9-G3-E & S6A2 & 21 & 18 & 0 & 0 \\
\hline 15 & K4-G1-E & S1S2S1 & 12 & 20 & 0 & 0 \\
\hline 16 & K14-G2-E & S2A1A2 & 18 & 20 & 0 & 0 \\
\hline 17 & K12-G3-E & S2A2A1S1 & 36 & 27 & 0 & 0 \\
\hline 18 & K10-G1-E & S4A6 & 35 & 27 & 0 & 0 \\
\hline 19 & K17-G2-K & S2A2A1S1 & 36 & 28 & 0 & 0 \\
\hline 20 & K9-G3-E & S6A2 & 21 & 28 & 0 & 0 \\
\hline 21 & K12-G3-E & S6A1A1 & 28 & 28 & 3 & 1 \\
\hline 22 & K13-G1-E & S4A1A1A1 & 40 & 50 & 0 & 0 \\
\hline 23 & K4-G1-E & S4A4S1 & 50 & 50 & 3 & 1 \\
\hline 24 & K12-G3-E & S6A2A2 & 63 & 63 & 3 & 1 \\
\hline 25 & K20-G2-K & S1A2S1A1 & 24 & 16 & 0 & 0 \\
\hline 26 & K16-G1-E & S1A1S1A2 & 24 & 16 & 0 & 0 \\
\hline 27 & K20-G2-K & S1A1S1A1 & 16 & 16 & 4 & 1 \\
\hline 28 & K15-G3-K & K2A2 & 9 & 40 & 0 & 0 \\
\hline 29 & K16-G1-E & S6A1A1A1 & 56 & 56 & 4 & 1 \\
\hline 30 & K8-G2-E & S4A1A4S1 & 100 & 100 & 4 & 1 \\
\hline 31 & K18-G3-K & S1A1 & 4 & 4 & 2 & 1 \\
\hline 32 & K18-G3-K & S6A4 & 35 & 35 & 2 & 1 \\
\hline
\end{tabular}

Tablo 3'te görüldüğü üzere, öğretmen adayları adidaktik aşamalarda 32 oyun oynamışlardır. Bu oyunların yarısını kazanmış ve yarısını kaybetmişlerdir. Seviye 1'de (oyun $1-7,10-13$ ve $31-32$ ) oynanan 13 oyunun yaklaşık \%77'sinin öğretmen adayları tarafından kazanıldığı belirlenmiştir. Seviye 2' de (oyun 8-9, 14-24) oynanan 13 oyunun ise sadece \%23'ü 
kazanılmıştır. Bunların son oyunlarda olduğu göze çarpmaktadır. Seviye 3'te ise (oyun 2530) toplam 6 oyun oynanmıştır. Bunların yarısının kazanıldığı tespit edilmiştir.

Seviye 1'deki oyunlarda kazanma oranının yüksek oluşu öğretmen adaylarının oyunu algıladığını ve oyundaki argümanları kullanabildiklerini göstermektedir. Bu bağlamda bazı örtük stratejilerinin olduğu da ifade edilebilir. Buradaki kazanan stratejiler incelendiğinde iki çarpana sahip sayıların elde edilmesini sağlayan bir strateji kullanıldığı anlaşılmaktadır. Bu strateji bulunması hedeflenen bakteri sayısının çarpanlarından biri satırda oluşturulduktan sonra diğeri sütunda oluşacak şekilde bakterinin çoğaltılması esasına dayanmaktadır. Seviye 1'deki bu strateji bakterilerin iki hamlede oluşturulmasını içermektedir. Ancak seviye 2' de bakteri kolonisinin sayısını elde etmek için 3 hamle gerekmektedir. Seviye 2' deki bakteri sayılarını oluşturmak için öğretmen adaylarının seviye 1'de örtük olarak keşfettikleri stratejileri kullanma eğiliminde oldukları birçok oyunda (oyun 8, 9, 14, 18 ve 20) oyunu 2 hamlede tamamlamak istemeleri şeklinde ortaya çıkmıştır. Bu durum seviye 2'deki birçok oyunun kaybedilmesi ile sonuçlanmıştır. Kaybetme pozisyonları öğretmen adaylarının stratejilerini kontrol etmesine ve revize etmesine yol açmıştır. Bu sayede bu seviyenin son oyunlarında tekrar kazanma pozisyonu oluşmuştur. Nitekim bu süreçte artık öğretmen adayları oyunda kazandıran strateji olduğunu düşündükleri hipotezleri vermeye başlamışlardır. Bunlardan oyun bağlamında reddedilen ve onaylanan örnekler aşağıda verilmiştir.

\section{Reddedilen Bir Hipotez Örneği (Oyun 8 ve 9)}

Ö: Seviye 2, evet, 8 (hedeflenen bakteri sayısı 8)

K8: Bana gelince zorlaşıyor. (S4A1 bastı, şu an 10 bakteri oldu)

K2: Gitti gitti

K1: Elendi

Ö: Bulamayız artık, çünkü 8'i aştığında artık olmuyor arkadaşlar.

K8: Yanlış oynadım ben (yeni oyun dedi) Rasgele basmayacă̆ım (S2A4 bastı).

Ö: O da olmadi.

\section{Onaylanan Bir Hipotez Örneği (Oyun 23)}

K4: Hocam 4, 4, 1 (S4A4S1bastı). Aha. Hocam şimdi. Istenen sayı mesela diyelim ki 50. Hocam ilk önce biz zaten 1'den başlıyoruz.

Ö: Arkadaşımız yaptı, şimdi hipotezini anlatıyor.

K4: Hocam, 1'i bir sayı ile çarpacă̆ız. 50'nin katlarına ulaşmamız için. Çarptığımız sayı o sayı ile çarpacă̆̆ı, ha o kadar ekleniyor. Mesela 1, biz 4 ile çarptık. 4 tane geliyor. Toplam 5 tane oldu.

Ö: 50 sayısına ulaşmak için, 1 var diyor arkadaşımız. 1+1x4=5 oluyor. Evet.

K4: Sonra bizim 25'e ulaşmamız lazım.

Ö: Sonra 25'e ulaşmamız lazım dedi. Evet.

K4: 25'e ulaşmak içinde bunu (5'i gösterdi) 4 ile çarparsak 20 ediyor. 5 tane de burada vardı. Toplamda 25 eder.

Ö: $5+4 \times 5=25$ olacak diyor, evet.

K4: Hocam, direk sonra 1 ile çarparsak 25 gelir 25, 25 daha 50 olur.

Ö: 25+1x25=50 olur, diyor. Evet, hipotez doğru mu?

Ks: Evet, doğru. 
$\mathrm{Bu}$ oyunlar incelendiğinde, kaybedilen oyunlarda bulunması hedeflenen bakteri sayısı 8 iken butonların bakteri ya da bakterileri nasıl çoğalttığı göz ardı edildiği ve sadece 8 sayısının çarpanlarına odaklanıldığı görülmektedir. Bu bağlamda oyun 8 ve 9 incelendiğinde K8 kodlu öğretmen adayının önce S4'e sonra A1'e basması bu sayede 10 bakteriye ulaştığında yanlış butona bastığını ifade etmesi ve yeniden oyunu oynadığında bu kez hedeflenen sayının çarpanlarına odaklanarak S4A2 butonlarına basması (dikkat edilirse 4 ve 2 sayıları 8 sayısının çarpanıdır) burada örtük de olsa bir strateji uygulandığını göstermektedir. Ancak bu strateji öğretmen adayı tarafından açık bir şekilde ifade edilmemiştir.

Kazanılan oyunda ise butonların işlevlerinin çözüldüğü ve hedeflenen sayıya ulaşılmasında ilk durumdaki bakteri, bu bakterilerin butonlarla çoğaltılması ve son durumda elde edilen bakteriler ile hedeflenen sayının çarpanları arasında ilişki kurularak kazandıran bir strateji verildiği anlaşılmaktadır. Bu bağlamda başlangıçta 1 bakteri ile başlanmıştır. İlk olarak 50 sayısının bir çarpanı olan 5'e ulaşılmaya çalışılmıştır. Bunun için S4 butonu tercih edilmiştir. Bu sayede 1 bakteri, 4 kez çoğaltılmış ve toplam 5 bakteriye ulaşılmıştır. Bu durum 1+4x1=5 şeklinde modellenebilir. Daha sonra 50 sayısının 5 'ten büyük diğer çarpanına ulaşmak amaçlanmıştır. Bu çarpan K4 kodlu öğretmen adayı tarafından 25 olarak ifade edilmiştir. Benzer şekilde son durumdaki 5 bakteri A4'e basılarak 4 kez çoğaltılmış ve 20 yeni bakteri elde edilmiştir. Dolayısıyla hamlenin başlangıcındaki bakteriler ( 5 bakteri) ile yeni üretilen ( 20 bakteri) birlikte düşünüldüğünde toplam $5+4 \times 5=25$ bakteriye ulaşılmıştır. Daha sonra ise 25 bakteri 1 kez çoğaltıldığında 50 bakteriye ulaşılacağ belirtilmiştir. Buradan 25+1x25=50 bakteri sayısı elde edilmiştir. Lokal bir strateji olarak ifade edilebilecek bu strateji sınıf tarafından onaylanmıştır. Bu strateji oyun 23'te verilmiştir. Bunun dışında da öğretmen adayları oyunda kazandıran strateji olduğunu düşündükleri bazı stratejiler vermiştir. Oyun sürecinde öğretmen adaylarının açık bir şekilde verdiği bütün stratejiler Tablo 4'te verilmiştir.

Tablo 4. Oyun sürecinde verilen hipotezler ve bunların doğrulanma durumu

\begin{tabular}{|c|c|c|c|c|}
\hline & Oyun & $\begin{array}{l}\text { Öğrenci } \\
\text { ve Grup }\end{array}$ & Sunulan Hipotez ve Doğrulanma Süreci & $\begin{array}{l}\text { Onay/ } \\
\text { Ret }\end{array}$ \\
\hline 1 & $\begin{array}{l}10,11, \\
12 \text { ve } \\
13\end{array}$ & K11-G2 & $\begin{array}{l}\text { Ö: Arkadaşımız hipotez veriyor. } \\
\text { K9: Hocam burada 1'i burada 1'i seçince 4, yeni oyun diyelim sonra buradan 2'yi buradan 2'yi } \\
\text { seçince 9, buradan 4'ü buradan 4'ü seçince 25, altı altı seçince 49, karesel ifadeler çıkıyor. } \\
\text { (oyunda bunları teker teker gösterdi) } \\
\text { Ö: Ben karesel sayıların bu sistemde nasıl bulunacağını buldum diyor. Hipotezi doğru kabul } \\
\text { ediyor musunuz? } \\
\text { Ks: Evet }\end{array}$ & 2 \\
\hline
\end{tabular}




\begin{tabular}{|c|c|c|c|c|}
\hline & & & Ö: O zaman art 2 puan aldi. & \\
\hline 2 & 14 & K9-G3 & $\begin{array}{l}\text { K9: Hocam benim hipotezim, buradaki sayıların çarpımı (sağa çoğaltan), buradakiler (aşă̆ı } \\
\text { çoğaltan) ise sıralamanın çarpımıdır. Mesela } 18 \text { sayısını bulacağız. } \\
\text { Ö: Arkadaşlarına anlat, bana değil. } \\
\text { K9: 6'ya bastığımızda } 6 \text { tane gelir, değil mi? Burada da } 2 \text { bastı̆̆ımızda } 2 \text { satır daha gelecek } 18 \\
\text { tane olur. } \\
\text { K8: } 21 \text { olur. (Gülüşmeler) } \\
\text { K14: Kendi kendini çürütttün, K9. }\end{array}$ & 0 \\
\hline 3 & 15 & K4 & $\begin{array}{l}\text { K4: Oyundaki bakteri sayısı seçilen sayı ile çarpılıyor. Aslında } 3 \text { sayının çarpımıdır. Mesela az } \\
\text { önce sayımız } 18 \text { di ya hocam. } 2 \text { yapsaydı toplam } 3 \text { tane bakterimiz olacaktı. Sonra 6'ya bassaydı } \\
18 \text { tane bakteri olacaktı. } \\
\text { Ö: (yeni oyun) Yap bakarım. 20'yi göster bize. (gösteremedi) } \\
\text { K4: Toplamı sayamadım hocam ben. (yanlış yaptığın fark etti) }\end{array}$ & 0 \\
\hline 4 & 21 & K9 & $\begin{array}{l}\text { K9: } 21 \text { saydı. (20.oyun) Az sayı seçeceğiz ki (sayıları küçük olan butonlara basmayı kastediyor) } \\
\text { buradaki sayıları ee aşmasın. } \\
\text { Ö: Ama olmuyor bak. } \\
\text { K9: (yeni oyun butonuna bastı) }\end{array}$ & 0 \\
\hline 5 & 23 & K4 & Yukarıda kazanan oyun örneği kısmında açıklandı. Bu yüzden tekrar yazılmadı. & 2 \\
\hline 6 & 24 & K12 & $\begin{array}{l}\text { Ö: Arkadaşımız hocam ben çarpanlarına ayırııım diyor. Ne yaptı? } \\
\text { K12: Çarpanlarına ayırdım. (63 sayısını çarpanlarına ayırıyor) } \\
\text { Ö: Çarpanlarına ayırdım dedi, evet. } \\
\text { K12: } 9 \text { kere 7, 63. İki iki. } \\
\text { Ö: Bak 2, 2'ye bastı } 9 \text { buldu. Daha sonra da... } \\
\text { K12: } 7 \text { yok.(parmaklarını şıklattı, elini ă̆zına götürdü) } \\
\text { K4: çıkmaz } \\
\text { Ö: Önce istersen 7'yi yap. Farklı bir bağlam yap. Bu da olurdu ama kolon sığmıyor. } \\
\text { K12: (6, 2, 2'ye bastı) } \\
\text { Ö:Neye bastın şimdi? } \\
\text { K12: } 1 \text { vardı zaten elimde, 7'yi bulmak için 6'ya bastım. Çünkü 63'ün bölenlerinde } 7 \text { var. 7'yi } \\
\text { bulmak için } 6 \text { ya bastım. Daha sonra tekrar 2'ye bastım aşă̆ıdan 21'i buldun. 21'den de 2'ye } \\
\text { bastım. } 63 \text { buldum. }\end{array}$ & 2 \\
\hline 7 & 32 & K18 & $\begin{array}{l}\text { K18: Benim de mantı̆̆ım arkadaşımınkine yakın. Burada hangi sayı çıkıyorsa, o sayıyı } \\
\text { çarpanlarına ayırıyorum. } 10 \text { 'a } 10 \text { (10x10), değil mi? Bizimde çarpanlarımızın bu sayılar } \\
\text { arasında olması gerekiyor. } \\
\text { Ö: Arkadaşımız çarpanlara odaklanmam gerekiyor, dedi. } \\
\text { K18: Aynen. (4 çıktı) } 2 \text { kere } 2 \text { dört. Yani üstte } 2 \text { olması lazım. Kenarda } 2 \text { olması lazım. Biz } \\
\text { burada 1'e bastığımızda } 1 \text { ekleniyor. Burada ise hangi sayıya basarsak o kadar satır artıyor. } \\
\text { Yani üstteki satırı saymıyorlar. } \\
\text { Ö: (Oyunu ilerletti) } 35 \text { mesela. }\end{array}$ & 2 \\
\hline 8 & - & $\begin{array}{l}\text { K4 ve } \\
\text { K11 }\end{array}$ & $\begin{array}{l}\text { K4: Asal çarpanların } 1 \text { eksiğini alacă̆ız. } \\
\text { Ö: Asal çarpanlarına ayıracă̆ız diyor. Sonra } 1 \text { eksiğini alacă̆ız diyor. } \\
\text { K4: Evet } \\
\text { K11: Ben de aynısını söyleyecektim.(K4'ün söylediğini kafasını aşă̆ı yukarı sallayarak } \\
\text { onaylıyor) }\end{array}$ & 2 \\
\hline
\end{tabular}

Adidaktik aşamalarda açık bir şekilde sınıfa sunulan ilk hipotez seviye 1'deki oyunlar bağlamında oyun 10'da K11 tarafından verilmiştir. Bu hipotez oyun bağlamında deneysel olarak onaylanmıştır. Ancak bu hipotez sadece birkaç sayı için doğru çözümler üretmektedir. Bu anlamda lokal bir çözüm olarak nitelendirilmektedir. Hipotez 2'den 6'ya kadar olan hipotezler seviye 2'de verilmiştir. Burada 2, 3 ve 4 . hipotezlerin yanlış olduğu ve bunun doğrulanma sürecinin oyunda deneysel olarak gerçekleştirildiği görülmektedir. Bu 
oyunlarda oyunun kaybedilmesinin verilen hipotezin de yanlış olduğu eğilimine yol açtığ1 gözlenmiştir. Bu hipotezlerin yanlış olarak ortaya çıkmasının kaynağının sağ ve alt çoğaltma butonlarının başlangıçta ya da sonrasında nasıl bir çoğaltma uyguladığı keşfedilmeden ve bu çoğaltma durumu göz ardı edilerek hipotezlerin sunulmasına bağlanmaktadır. Ancak 5 ve 6 . hipotezler incelendiğinde artık bakterilerin herhangi bir anda bir hamle yapıldıktan sonra nasıl çoğalacağı bilgisinin keşfedildiği ve hipotezlerin bu bağlamda verildiği belirlenmiştir. $\mathrm{Bu}$ yaklaşım hedeflenen bakteri sayısının çarpanlarına odaklanılarak çözüm gerçekleştirilmesini doğurmuştur. Bu durum 7. hipotezde de benzer şekilde gerçekleşmektedir. Öğretmen adidaktik aşamalardan kurumsallaştırma aşamasına geçme sürecinde iki farklı gruptan iki öğrencinin (K4 ve K11) benzer şekilde 8. hipotezi verdiği görülmektedir. Bu hipotez iki farklı gruptaki (grup1 ve grup 2) bireyler tarafından aynı şekilde ortaya atılması ve daha önce onaylanan stratejilerin bir genellemesi olması sebebiyle herkes tarafından kabul edilmiştir. Bu bağlamda çözümün genel bir çözüm olduğu söylenebilir. Bu aşamalar toplam 34 dakika sürmüştür.

\section{Kurumsallaştırma Aşaması}

$\mathrm{Bu}$ aşama oyun bağlamında elde edilen bilginin matematiksel olarak ne anlama geldiğinin açıklanması, matematiksel bilgi ile oyun arasındaki çift yönlü ilişkinin nasıl kullanıldığının anlaşılması noktasında büyük bir öneme sahiptir. Bu doğrultuda sınıfın lokal çözümlerinin (sayının asal çarpanlarından ziyade çarpanlarına odaklanarak verilen çözümler ya da birkaç sayı için çözüm yolu sunan stratejiler) öğretmen adayları tarafından bir adım öteye taşınarak genel bir çözüm elde edilmiştir. Öğretmen bu genel çözümü sınıfa aşağıda verildiği şekliyle sunmuştur.

\footnotetext{
Ö: Problemin tam çözümü buydu. Bu oyunda karşınıza gelen sayıyı asal çarpanlarına ayıracaksınız. Birer eksiklerini aldığınız zaman elde ettiğiniz butonlara bastığınızda, daima o sayıyı bulursunuz. Mesela, 28 alalım. 28'in çarpanların buluyorum. 2, 2, 7 dir. 1, 1 ve 6'ya basarsanız 28'i bulursunuz. Ama önce büyük sayıya basmak gerekebiliyor. Çünkü bazen kolonlar yetmiyor. Ama normalde $(1,1,6),(6,1,1),(1,6,1)$ hepsi de olur. Ama oyun alanımız yetmediği için bazen farklı kombinasyonlar yapmak gerekiyor.
}

Bu açıklamalardan da anlaşılacağı üzere, öğretmen adaylarının verdiği genel çözüm üzerinden oyunda buldurulması hedeflenen matematiksel bilgi onların anlayacağı şekilde bir kez daha sunulmuştur. Daha sonra 28 bakteri sayısı örneği üzerinden oyun ile hedef bilgi arasında nasıl bir ilişki kurulduğu açıklanmıştır. Bu bağlamda 28 sayısının asal çarpanlarına ayrılışının 28=2x2x7 biçiminde olduğu ve oyunda bu asal sayıların birer eksiği olan butonlara basıldığında daima 28 sayısının elde edileceği belirtilmiştir. Ayrıca bunun birden 
çok yolunun olduğu da açıklanmıştır. Burada birçok kombinasyon olduğuna da işaret edilmektedir. Bunlardan bazılar1 S1S1A6, A1A1S6, A6S1S1, S6A1A1, S1A6S1, A1S6A1 şeklinde ifade edilebilir. Diğer taraftan burada bazı çözümlerin oyunda oyunun sinırlılıklarından dolayı (örneğin oyun alanının 10x10 şeklinde organize edilmesi) uygulanamayacağı da ifade edilmiştir. Bu çözümlerden bazıları S1S1S6, A1A1A6, A1S1A6, A1S1S6, S1A1S6, S1A1A6 şeklinde gösterilebilir. Kurumsallaştırma aşamasının diğer bir önemi gerçekleştirilen matematiksel bilginin oyunda tamamen incelenmesi yerine (örneğin 1'den büyük bütün doğal sayılarda), matematiksel bilginin sınırlandırılmış bir ölçekte (1'den 100'e kadar olan sayılar içerisinde böleni tek basamaklı asallar olan bazı sayılarda) incelenmesi olarak açıklanabilir. Bunu sezgisel olarak fark eden bir öğrencinin aşağıda öğretmene yönelttiği soru oyunda buldurulması hedeflenen bilginin farklı boyutlarının ortaya çıkarılması adına öğretmene fırsat yaratmıştır.

K8: Hocam peki 79'u nasıl bulacaksinız burada.

Ö: Ha. Mesela 79 sayısı asal sayı, değil mi? Burada bazı asallar yapılabiliyor (2, 3, 5 ve 7 kastediliyor). Dikkat ederseniz 2, 3, 5, 7 ile yapılan birleşik sayılar çıkıyor. Mesela 40 sayısı, 2x2x2x5 tir. Bu oyunda bunların birer eksiğini aldığınızda daima bu sayıyı bulabilirsiniz. Öğretmeye çalıştığımız şey Aritmetiğin Temel Teoremidir. Yani 1'den büyük her doğal sayının asal çarpanlara ayrılışı tektir. Dolayısıyla bu sistemde onu asalların birer eksiğini alarak bulabilirsiniz. Aslında burada 1, 2, 4, 6 sayıları vardı ya. Onlar nedir biliyor musunuz? Bakın, 1, 2, 4, 6 sayıları aslında asal sayıları ifade ediyor. Şuna 1 ekleyin 2, şuna 1 ekleyin 3, şuna 1 ekleyin 5, şuna 1 ekleyin 7 dir. Aslında benim bu oyunda bulmanızı istediğim sayılar rastgele sayılar değildi. Bakın 3'ü yazmadım. Niye yazmadım. 3'ün 1 fazlası asal değil. Buradaki butonlar asal sayılar temsil ediyor zaten. Mesela 28'i bulmak istiyorsun ya. 28'in çarpanları nedir? 2x2x7 dir. Bu saylara 1 eklediğinizde hangi sayılara basmanı gerektiği ortaya çıkıyor.

$\mathrm{Bu}$ diyalogda matematiksel bilginin sınırlandırılarak oyun içerisine saklandığı anlaşılmaktadır. Burada oyun alanının 10x10 şeklinde olması oyunda 1'den 100'e kadar olan sayılar üzerinde çalışıldığını ve sadece 2, 3, 5 ve 7 ile oluşturulabilecek şekilde sayılar elde edilebileceği vurgulanmıştır. Bu sınırlamanın bir sonucu olarak 79 gibi bir sayı bu sistemde bulunamamaktadır. Benzer şekilde 101 sayısı da burada elde edilemeyecektir. Ancak bu tür durumlar oyunda saklanan matematiksel bilginin ortaya çıkmasına engel teşkil etmemektedir. $\mathrm{Bu}$ sadece matematiksel bilginin belli sınırlılıklar ve koşullar altında incelenmesini işaret etmektedir. Bu durumun nedenlerinden bazıları araştırmacının tasarımını bu doğrultuda sunması ve teknolojinin matematiğin bütün boyutlarını yansıtmakta yetersiz kalmasıyla açıklanabilir. Bu durum başka bir öğrencinin benzer bir sorusuyla daha da netlik kazanmıştır. Bu doğrultuda sınıftaki diyaloglar aşağıda verilmiştir.

K4: Hocam asal sayılarda să̆lamıyor, değil mi? Mesela 23.

Ö: Bu tür asal sayıları oyunda zaten vermedim. Ha, bunlar bu oyunda bulamazsinı. Ancak yaklaşabilirsiniz. 24 yapabilirsiniz. Yani bu sistemde 2, 3, 5 ve 7 asal sayılart ile hangi sayılar yapılabiliyorsa onları bulabilirsiniz. Tabii 100'ü geçmeyecek şekilde. Mesela 23 bulamazsınız. 23'ün 2 çarpanı yok. 3 çarpanı 
yok. 5 çarpanı yok. 7 çarpanı yok. Demek ki burada Aritmetiğin Temel Teoremi bulunmaya çalışılıyormuş. O da, 1 den büyük doğal sayıların asal çarpanlarına ayrılışının tek türlü (sıralamaya dikkat edilmezse) olduğunu ifade eder.

Burada öğretmen bir önceki alıntıda vurgulanan oyundaki sınırlılıklar ve koşullar doğrultusunda bazı sayılara ulaşılamayacağını yinelemiştir. Diğer taraftan oyunda seçilen sayıların sınırlılıklar ve koşullar dikkate alınarak seçildiği ifade edilmiştir. Son olarak oyunda bulunması hedeflenen matematiksel bilgi olan Aritmetiğin Temel Teoremi verilmiştir. Aritmetiğin Temel Teoremi "Birden büyük her tamsayı asal sayıların bir çarpımı olarak yazılır ve bu çarpım tek türlü olarak ifade edilir" şeklinde tanımlanmaktadır (Dönmez, 2002). Burada söz konusu sayıların çarpanlarının sıralama gözetilmeksizin verildiği unutulmamalıdır. Bu aşama 7 dakika sürmüştür.

\section{Bakteri Kolonisi Oyunundan Bir Yansitma}

$\mathrm{Bu}$ çalışmada sınıf öğretmeni adayları, mobil oyunların matematik eğitiminde matematiksel bilginin yapılandırılması sürecinde nasıl kullanılabileceğinin bir örneğini deneyimlemiştir. Bu deneyimlemenin sadece Aritmetiğin Temel Teoreminin tanitılmasıyla sınırlı kaldığını söylemek yanlış olacağı varsayılmaktadır. Deneyimleme olgusunun gereği insanlar yaşadıkları ilginç bir deneyim ile ilgili en az iki şeyi hatırlayabilmektedir. Bunlardan birincisi deneyimlenen olgu, diğeri ise deneyimleme sürecidir. Bu çalışmada üç husus üzerinde durulmaktadır. Birincisi matematiksel bilginin mobil oyun yoluyla sunulması, keşfedilen matematiksel bilgi ve matematiksel bilginin keşfedilme sürecidir.

İlk olarak matematiksel bilginin mobil oyunun içine gizlenmesi etkinliğin hemen fark edilmeyen sürecini oluşturmaktadır. Bu süreçte matematiksel bilgi ilk olarak küçük hedefler ya da amaçlar biçiminde parçalanır. Daha sonra bunlar sınırlılıklar ve koşullar ile çevrelenerek oyun bağlamında ve oyunun kuralları doğrultusunda keşfedilmesine yönelik ortam organize edilir. Bu boyut, matematiksel bilginin öğretim amaçlı olarak mobil oyunda gizlenmesine yönelik birçok süreç barındırmaktadır. Tüm bu dönüşümlerin sonrasında matematiksel bilgi mobil oyun içerisinde gizli bir şekilde oyuncuya sunulmaktadır. Bu süreçler büyük ölçüde uzmanlık gerektirdiğinden öğretmen adaylarının bunlarla ilgili farkındalık geliştirip geliştirmediği çalışmada tartışılmamıştır.

Deneyimlemenin ikinci boyutunda, deneyimlenen olgu yer almaktadır. Burada bu olgu öğretmen adaylarının Aritmetiğin Temel Teoremini bir mobil oyun içerisinde sınırlı bir sistemde keşfetmeleri olarak açıklanabilir. Aritmetiğin Temel Teoremi ile ilgili tanımın 
verilmesi, farklı örnekler üzerinden bunun anlatılması ve bazı sayılara bu sistemde niçin ulaşılamadığının açıklanması bu bağlamda değerlendirilebilir. Bu önemli olmakla birlikte daha önemli olan kısım bu süreçlerde nelerin yaşandığı, süreçlerin nasıl ilerlediği, süreçlerde hangi etkileşimlerin olduğu ve bu etkileşimlerin yönü ile ilgilidir. Bu ise son süreç olan deneyimleme süreci olarak değerlendirilmektedir.

Bu etkinliği öğretmen adaylarının deneyimleme süreci incelendiğinde yapılandırmacı yaklaşıma uygun bir öğretim tasarımı gerçekleştirildiği belirtilebilir. Bu doğrultuda öğretmen adaylarının bilgiyi kendilerinin yapılandırması adına öğretmen tarafından ortama dijital milieu olarak ifade edilebilecek bir mobil oyun sunulmuştur. Öğretmen adayları mobil oyun ile mücadele içerisine girdiklerinde farkında olmadan birçok matematiksel nesne ile meşgul olmuşlardır. Bu süreçte mobil oyundan aldıkları dönütler vasıtasıyla kazandıran stratejiler ve hipotezler oluşturmaya çalışmışlardır. Bunların doğru olup olmadığını öğretmene sormak yerine oyunda test ederek karar vermişlerdir. Doğrulanan her hipotez adım adım hedef bilgiye öğretmen adaylarını yöneltmiştir. Sonunda mobil oyunun arkasında yatan bilgiye yine oyun bağlamında ulaşmışlardır. Tüm bu deneyimleme süreci bir matematiksel bilginin bir bireyde yapılandırmacı bir paradigma bağlamında oluşturulması süreçleriyle paralellik arz etmektedir. Öğretmen adaylarının matematik eğitimi gibi özel bir disiplinde bu süreçleri deneyimlemelerinin onların yapılandırmacı ortam tasarımlarına ilişkin birçok farkındalık geliştireceği belirtilebilir. Bu bağlamda bu çalışmada DDT'nin aşamalarında öğretmen adaylarının maruz kaldığı bazı durumlar aşağıda verilmiştir:

- Sorumluluk aktarma aşamasında öğretmen ile mobil oyun etkileşimini öğretmen adaylarının gözlemlemesi,

- Adidaktik aşamalarda mobil oyun-öğretmen adayları, öğretmen adayları-öğretmen adayları ve öğretmen adayları-öğretmen ikilileri arasında etkileşim,

- Kurumsallaştırma aşamasında öğretmen-öğretmen adayları-matematiksel bilgi etkileşimidir.

DDT'nin farklı aşamalarında etkileşimler değişik şekillerde farklı yönlerde ortaya çıkmıştır. Örneğin sorumluluk aktarmada öğretmenden öğrenciye bir aktarım söz konusu iken, adidaktik aşamalarda öğretmenin süreçte zayıf bir aktör olduğu ve öğretmen adayları ile mobil oyun arasında güçlü bir etkileşim olduğu anlaşılmaktadır. Kurumsallaştırma 
aşamasında ise öğretmen, matematiksel bilgi ve öğretmen adayları arasında ikili ilişkiler hissedilmektedir. DDT'nin farklı aşamalarında öğretmen adaylarının kendilerinin bir mobil oyun yoluyla Aritmetiğin Temel Teoremini farklı süreçlerden geçerek keşfetmeleri bu süreçler hakkında bir fikir edinebileceklerini düşündürmektedir. Dolayısıyla öğretmen adaylarının buradaki süreçlerle ilgili birçok farkındalık geliştirdiği söylenebilir.

\section{Tartışma, Sonuç ve Öneriler}

Sınıf öğretmeni adaylarının Aritmetiğin Temel Teoremini bir mobil oyun aracılığı ile keşfetme sürecinin incelendiği çalışmada, sınıf öğretmeni adaylarının Aritmetiğin Temel Teoremine tasarlanan ortamın parametreleri doğrultusunda ulaştıkları belirtilebilir. Ayrıca öğretmen adaylarının yapılandırmacı yaklaşıma uygun bir ortam tasarımında Aritmetiğin Temel Teoremine ulaşmalarının, onların yapılandırmacı ortamın paradigmalarının birçoğunu fark etmelerini sağladığı da belirtilebilir. DDT'nin aşamalarının bu bağlamda etkili bir yol sunduğu sonucuna ulaşılmıştır. Aşamalarda öğretmen adaylarının davranışları daha detaylı olarak izleyen paragraflarda tartışılmıştır.

Sorumluluk aktarma aşamasında öğretmen adaylarının oyunun kurallarını tam anlamıyla anladığı görülmektedir. Bunun en önemli göstergesi adidaktik aşamaların başındaki oyunlarda kazanma oranının yüksek çıkmasıdır. Bu süreçteki oyunlar genellikle seviye 1'de uygulanmıştır. Bu seviyedeki aşamalarda bakteri sayısının iki asal çarpana sahip olduğunu örtük bir şekilde fark eden öğretmen adaylarının bunları satır ve sütunda iki hamlede oluşturmasıyla oyunu kazandıkları belirlenmiştir. $\mathrm{Bu}$ anlamda öğretmen adaylarının lokal bir takım çözüm yollarını doğru bir şekilde burada kullandıkları söylenebilir. Oyunda seviye 2'ye gelindiğinde kazanma oranının dramatik bir şekilde düştüğü tespit edilmiştir. Bu durum seviye 1'deki kazandıran stratejinin seviye 2'deki aşamalara yanlış bir şekilde aktarılmasıyla açıklanabilir. Nitekim birçok öğretmen adayının seviye 2'deki aşamalarda bakteri sayısına 2 hamlede ulaşmak istemesi bu iddiayı kuvvetlendirmektedir. Farklı bir açıdan, oyunda seviye 1 ve seviye 2'de kullanılan sayıların asal çarpan sayıları ile ilgili özelliklerinin aynı olmaması kazanma-kaybetme pozisyonunu etkilemiştir. Bu doğrultuda 23. oyuna kadar verilen çoğu hipotezin oyun bağlamında reddedildiği tespit edilmiştir. Diğer taraftan bu durum oyunun süreçlerinin yeniden irdelenmesine yol açmış, bu doğrultuda hipotezler revize edilmiş ve daha sağlam hipotezler verilmeye başlanmıştır. Bu sürecin kırılma noktası, oyundaki bakterilerin herhangi bir anda 
yapılan bir hamle sonrasında ne kadar artış gösterdiği bilgisinin keşfedilmesiyle başladığ anlaşılmıştır. Bu kırılma anının ilk yansıması olarak görülebilecek oyun 23'te hamle sonrası bakterideki artış dikkate alınmış ve hamlenin sonunda bakteri sayısı ile ulaşılmak istenen bakteri kolonisinin çarpanları arasında K4 kodlu öğretmen adayı ilişki kurarak onaylanan bir hipotez sunmuştur. Bu hipotez, ulaşılmak istenen sayının çarpanları elde edilecek şekilde, var olan bakterilerin katlanması esasına dayanmaktadır. Diğer onaylanan hipotezlerde de benzer şekilde bulunması hedeflenen bakteri sayısının çarpanlarına katlamalar yoluyla ulaşıldığ1 ifade edilebilir. Dolayısıyla bu çözümlerin tamamının lokal çözümler olduğu belirtilebilir. Bu lokal çözüm yolları da süreç içerisinde gelişim göstermiştir. Bu bağlamda sayının katlanmasıyla rastgele çarpan bulmadan 1 ile 10 arasında çarpanlarına odaklanmaya doğru bir eğilim gözlenmiştir. Sonrasında farklı gruplardan iki öğretmen adayı her aşamada ulaşılması istenen bakteri kolonisi sayısının sahip olduğu asal çarpanlar ile oyundaki çoğaltma butonları arasındaki ilişkiyi fark ederek genel çözümü ortaya koymuştur.

$\mathrm{Bu}$ çalışmada kurumsallaştırma aşamasına özel bir değer atfedilmesi gerektiği düşünülmektedir. Bunun nedeni kurumsallaştırma aşamasında öğretmen adaylarının oyunda hedeflenen bilgiye ulaşılacak stratejiyi anlamlandırmanın ötesine geçebilecek bir eylemde bulunmasıdır. $\mathrm{Bu}$ bağlamda $\mathrm{K} 8$ ve $\mathrm{K} 4$ öğretmen adaylarının oyunda ulaşılamayacak bazı sayıların olduğunu fark etmeleri ve bunlara niçin ulaşılamadığını merak etmeleri öğretmene sayıların çarpanlarına ilişkin özellikleri farklı bir boyuta taşıma fırsatı yarattığı belirlenmiştir. Bu bağlamda farklı örnekler üzerinde Aritmetiğin Temel Teoremi ile ilgili öğretmen adaylarının anlayışlarının derinleştirildiği gözlenmiştir. Kurumsallaştırma aşamasında vurgulanması gereken diğer önemli noktalar, öğretmenin mobil oyun bağlamında çoklu çözüm yollarına izin verecek şekilde oyunun tasarlandığını belirtmesi ve sıralama ya da bakterilerin oluşturulma sürecinde değişiklik olsa da oyun bağlamında basılan butonların değişmediğinin açıklanmasıdır. Bu bağlamda butonların bu mobil oyundaki fonksiyonunun ne olduğu sorusu akla gelmektedir? Mobil oyunda bakterileri çoğaltmak için kullanılan butonların aslında tek basamaklı asallar olduğu ve oyunda tek basamaklı asallarla oyunun sinırlılıkları bağlamında sonlu sayıda sayıya ulaşılacağı belirtilmiştir.

Aritmetiğin Temel Teoreminin öğretmen adaylarına mobil bir oyun ile keşfettirilmesi sürecinde teoremin formal anlamda ve bire bir ortaya çıkması beklenmemektedir. Bu tür tasarımlarda formel tanımın çıkması olası olmakla birlikte, sınıf öğretmeni adaylarının bu 
bilgiyi keşfetmeleri ile kastedilen daha çok işlevsel bir şekilde bir bağlamda onun araç olarak kullanabilmeleridir. Nitekim farklı matematiksel bilgilere oyun bağlamında ulaşılmaya çalışıldığı birçok çalışmada formel tanımlara ulaşılması gerekmediği ve bu bağlamda informel tanımlamaların yeterli olduğu belirtilmektedir (Gök \& Arık, 2019). Burada önemli olan şeyin tanımlanan fikre odaklanılması gerektiğidir (Usiskin, Peressini, Marchisotto, \& Stanley, 2003). Bu ise matematiksel bir bilginin ihtiyaç hissedildiğinde belli bir amacı gerçekleştirmek için araç olarak kullanılabilmesini içermektedir (Warfield, 2014). DDT çerçevesinde tasarlanan adidaktik durumlar bu bağlamda değerlendirilebilir.

$\mathrm{Bu}$ çalışmanın diğer bir boyutunda, matematiksel bilgisinin bir mobil oyun ile sunulmasının yanı sıra bu oyunu öğretmen adaylarının deneyimlemesiyle birlikte matematiksel bilginin keşfedilmesi ve matematiksel bilginin yapılandırılması sürecinde gözlenen etkileşimlere ilişkin sonuçlara yer verilmiştir. İlk olarak, matematiksel bilginin mobil bir oyun içine gizlenerek sunulması bilginin öğretim amaçlı dönüştürülmesi kavramını (Chevallard, 1991) hatırlattı̆̆ı belirtilebilir. Bu çalışmada bu süreç öğretmen tarafından gerçekleştirilmiş olup çalışma bağlamında incelenmemiştir. Bununla birlikte, bu sürecin teknolojinin öğretime yönelik tasarımlar geliştirilmesinde önemli rol oynadığına işaret edilmektedir. Bu çalışmada mobil oyunlar aracılığıyla DDT’ye göre tasarlanan bir ortamda Aritmetiğin Temel Teoreminin öğretmen adayları tarafından keşfedilmesinin, DDT'nin mobil oyunların tasarımında etkili olarak kullanılma potansiyeli olduğunu göstermektedir. Bu bağlamda bu çalışma matematik öğretimine yönelik bakış açımıza yenilikçi bir perspektif sunmakta ve benzer nitelikteki çalışmaların yapılmasına yönelik araştırmacıları cesaretlendirmektedir. Son olarak, sınıf öğretmeni adaylarının Aritmetiğin Temel Teorisinin bir mobil oyun vasitasıyla DDT'ye göre tasarlanan bir ortamda keşfedilmesine ilişkin deneyimleme sürecinde yapılandırmacı yaklaşımların birçok bileşenine belli ölçüde değinildiği görülmektedir. Deneyimlemenin bir öğrenme yaklaşımı olduğu varsayımıyla, öğretmen adaylarının yapılandırmacı yaklaşımlara ilişkin birçok farkındalık geliştirdiği söylenebilir. Bunun göstergelerinden biri öğretim sürecinin başından sonuna kadar öğrenme ortamında yapılandırmacı yaklaşım izlerinin gözlenmesidir. Öğretmen adaylarının tasarlanan ortam ile etkileşim sürecinde bilgiyi inşa etmeleri ve bu sürece aktif katılımları bunun açık örneklerini yansıtmaktadır. Burada aksi bir durumla karşılaşılsaydı öğretmen ve öğrenciler arasında kurulan didaktik sözleşmenin varlığı açıkça 
hissedilecekti. Nitekim bazı çalışmalarda bu tür ihlallerin olabileceği belirtilmektedir (Brousseau, Sarrazy \& Novotná, 2014; Erdoğan, 2016).

Eğitsel dijital oyunların eğitimde kullanımının yaygınlaştığı günümüzde, öğretmen adaylarının dijital oyunların sınıf ortamında nasıl kullanılması gerektiği ve bazı uygulamaları eğitim amaçlı kullanmak için nasıl uyarlayacaklarını bilmelerinin büyük bir önem taşıdığı belirtilebilir. Bu çalışmada sınıf öğretmeni adaylarına bunun bir örneği deneyimletilerek sınıfta mobil oyunların nasıl kullanılabileceği gösterilmiştir. Bu konunun önemine işaret eden Sqire (2005), eğitici pozisyonundakilerin eğitimi takviye için dijital oyunlardan nasıl yararlanacaklarını bilmelerinin yanı sıra en popüler oyunların eğitsel bir araç olarak nasıl değiştirilebileceği bilgisine de sahip olmaları gerektiğini belirtmiştir. Bu bağlamda Taşdemir ve Şüyun (2016), Tetris oyununun yok etme ve görsellik özelliğinden yararlanarak matematiksel işlemlerin pekiştirilmesini sağlayan bir etkinlik tasarlamıştır. Aynı çalışmada eğitsel oyunların eğlenerek öğrenmek için uygun bir araç olduğu ve eğitim için etkili bir yöntem olduğu belirtilmiştir. Bu tür yöntemleri eğiticilerin bilmesinin ve kullanmasının yanında eğitimde dijital içerik geliştirme süreçlerine de öğretmenlerin dahil edilmesi gerektiği belirtilmektedir (MEB, 2018b). Ancak bu sürece çok az eğiticinin dahil olduğu belirtilmektedir (Rock \& Brumbaugh, 2013).

- Bilginin oyunlaştırılarak teknolojik araçlar ile sunulduğu ortam tasarımlarına ilişkin çalışmaların sayısının arttırılması gerektiği düşünülmektedir. Bu tür uygulamaların yaygınlaştırılmasıyla öğretmen adaylarının eğitim sürecinde daha aktif yer almaları sağlanabilir. Dahası öğretmen adaylarının bu tür yenilikçi yaklaşımları sınıf ortamında nasıl kullanabileceklerine yönelik süreçler içselleştirilebilir.

\section{Bilgilendirme}

Bu çalışmada kullanılan veriler 2020 yılı öncesine ait olduğu araştırmacı tarafindan onaylanmıştır.

\section{Yazar Katkı Beyanı}

Mustafa GÖK: Kavramsallaştırma, metodoloji, danışmanlı ve denetim (öğretim materyali, ölçme aracı, veri analizi), inceleme-yazma ve düzenleme 


\section{Kaynaklar}

Aktaş, M., Bulut, G.G. \& Aktaş, B.K. (2018). Dört işleme yönelik geliştirilen mobil oyunun 6. sınıf öğrencilerinin zihinden işlem yapma becerisine etkisi. JRES, 5(2), 90-100.

Altun, M. (2013). Ortaokullarda (5, 6, 7 ve 8. sinıflarda) matematik öğretimi (9. Bask1). Bursa: Alfa Akademi.

Arkün-Kocadere, S., \& Samur, Y. (2016). Oyundan oyunlaştırmaya. In A. Şiman, H. F. Odabaşı, \& B. Akkoyunlu (Eds). Eğitim teknolojileri okumaları, 397-415. Ankara: TOJET.

Artym, C., Carbonaro, M., \& Boechler, P. (2016). Pre-Service Teachers Designing and Constructing 'Good Digital Games'. Australian Educational Computing, 31(1). Retrieved from http://journal.acce.edu.au/index.php/AEC/article/view/91

Aşkar, P. \& Olkun S. (2005). PISA 2003 sonuçları açısından bilgi ve iletişim teknolojileri kullanımı. Eurasian Journal of Educational Research, 19, 15-34.

Baykul, Y. (2014). Ortaokulda matematik öğretimi (5-8. sinıflar). Ankara: Pegem Akademi.

Bishop, A. J. (1991). Environmental activities and mathematical culture. In Mathematical Enculturation (pp. 20-59). Springer, Dordrecht.

Brousseau, G., Sarrazy, B., \& Novotná, J. (2014). Didactic contract in mathematics education. In S. Lerman (Ed.), Encyclopedia of Mathematics Education, (pp. 153-159). Dordrecht: Springer Netherlands.

Cahyono, A. N. (2018). Learning Mathematics in a Mobile App-Supported Math Trail Environment. Cham (Switzerland): Springer International Publishing

Chevallard, Y. (1991). La transposition didactique du savoir savant au savoirenseigné. La transposition didactique du savoir savant au savoir enseigné avec un exemple d'analyse de la transposition didactique (pp.1-124). Grenoble: La Pensée Sauvage Edition.

Cop, M. R., \& Kablan, Z. (2018). Türkiye'de eğitsel oyunlarla ilgili yapılmış çalışmaların analizi. Kocaeli Üniversitesi Eğitim Dergisi, 1(1), 52-71.

Çetin, Y. \& Mirasyedioğlu, Ş. (2019). Teknoloji destekli probleme dayalı öğretim uygulamalarının matematik başarısına etkisi. Journal of Computer and Education Research, 7 (13), 13-34. DOI: 10.18009/jcer.494907

Çubukluöz, Ö. (2019). 6. sınıf öğrencilerinin matematik dersindeki öğrenme zorluklarının scratch programıyla tasarlanan matematiksel oyunlarla giderilmesi: bir eylem araştırması (Master's thesis, Bartın Üniversitesi, Eğitim Bilimleri Enstitüsü).

Deterding, S., Sicart, M., Nacke, L., O’Hara, K., \& Dixon, D. (2011). Gamification: Using game-design elements in nongaming contexts. Proc. CHI EA '11, ACM Press, 24252428, ACM 978-1-4503-0268-5/11/05.

Domínguez, A., Saenz-de-Navarrete, J., De-Marcos, L., Fernández-Sanz, L., Pagés, C., \& Martínez-Herráiz, J. J. (2013). Gamifying learning experiences: Practical implications and outcomes. Computers $\mathcal{E}$ Education, 63, 380-392.

Dönmez, A. (2002). Matematik terimleri ve formülleri. Ankara: Seçkin Yayıncılık.

Durgut, A. (2016). Meslek Yüksekokulu öğrencileri için eğitsel matematik oyunu geliştirilmesi ve başarıya etkisinin incelenmesi (Master's thesis, Balıkesir Üniversitesi Fen Bilimleri Enstitüsü). 
Erdoğan, A. (2016). Didaktik sözleşme. E. Bingölbali, S. Arslan, \& İ. Ö. Zembat (Eds.), Matematik eğitiminde teoriler içinde (s. 565-580). Ankara: Pegem.

Faghihi, U., Brautigam, A., Jorgenson, K., Martin, D., Brown, A., Measures, E., \& MaldonadoBouchard, S. (2014). How gamification applies for educational purpose specially with college algebra. Procedia Computer Science, 41, 182-187.

Genç, E. D., Issı, H. N., \& Yıldız, O. (2017). Matematik öğretimi için nokta belirleme tekniğine dayalı bir mobil uygulama. Istanbul Journal of Innovation in Education, 3(1), 55-62.

Gök, M., İnan, M., \& Akbayır, K. (2017). Teaching the fundamental theorem of arithmetics to prospective primary school teachers by designing a mobile game. Paper presented at the International Conference on Research in Education and Science (ICRES), Aydin, Türkiye.

Gök, M. \& Arık, M. (2019). İlköğretim matematik öğretmeni adaylarının yapılandırmacı bir ortam deneyimi: Kesirleri birim kesirlerin toplamı olarak yazma. Turkish Studies Educational Sciences. 14(5), 2345-2364. DOI: 10.29228/TurkishStudies.36955

Kiili, K. (2005). Digital game-based learning: Towards an experiential gaming model. Internet and Higher Education, 8, 13-24. doi:10.1016/j.iheduc.2004.12.001

Kim, B., Park, H., \& Baek, Y. (2009). Not just fun, but serious strategies: Using meta-cognitive strategies in game-based learning. Computers $\mathcal{E}$ Education, 52(4), 800-810.

Kukul, V. (2013). Oyunla ilgili tarihsel gelişim ve yaklaşımlar. M. Ocak içinde, Ĕ̆ itsel Dijital Oyunlar (s. 29-30). Ankara: Pegem Akademi.

Laborde, C. (2007). Towards theoretical foundations of mathematics education. ZDM Mathematics Education, 39, 137-144.

Leatham, K. R., \& Barton, D. R. (2017). What (Research on) Technology in the Mathematics Classroom Can and Cannot Do. In D. A. Spangler \& J. J. Wanko (eds), Enhancing classroom practice with research behind Principles to actions, 129-140. Reston, VA, NCTM.

Ligozat, F. \& Schubauer-Leoni, M. L. (2010). The joint action theory in didactics: Why do we need it in the case of teaching and learning mathematics? In V. Durand-Guerrier, S. Soury-Lavergne \& F. Arzarello (Eds.), Proceedings of the 6th Conference of European Research in Mathematics Education (CERME 6) (pp. 1615-1624). Lyon: Institut National de la Recherche Pédagogique.

Måsøval, S. H. (2009). Complexity of operating beyond naïve empiricism when proving a conjectured formula for the general term of a geometrical pattern. In Carl, Winsløw (Ed.), Proceedings of Nordic Research in Mathematics Education (NORMA08)(pp. 25-34). Rotterdam: Sense Publishers.

Merriam, S. B. (2013). Nitel vaka çalışması (Çev: E. Karadağ). S. Turan (Ed.), Nitel araştırma desen ve uygulama için bir rehber içinde (3rd ed.). Ankara: Nobel.

Milli Eğitim Bakanlığı [MEB]. (2018a). Matematik dersi öğretim programı (İlkokul ve Ortaokul 1, 2, 3, 4, 5, 6, 7 ve 8. Sinıflar). Ankara: Milli Eğitim Bakanlığı.

Milli Eğitim Bakanlığı [MEB]. (2018b). 2023 eğitim vizyonu. Ankara: Milli Eğitim Bakanlığı. Retrieved December 27, 2018, from http://2023vizyonu.meb.gov.tr/doc/2023 EGITIM VIZYONU.pdf 
National Council of Teachers of Mathematics (1989). Curriculum and evaluation standards for school mathematics., VA: Reston.

National Council of Teachers of Mathematics. (2000). Principles and standards for school mathematics. VA: Reston.

Ozel, S., Yetkiner, Z. E., \& Capraro, R. M. (2008). Technology in K-12 mathematics classrooms. School Science and Mathematics, 108(2), 80-85.

Özdener, N., \& Demirci, F. (2019). Determining students' views about an educational gamebased mobile application supported with sensors. Technology, Knowledge and Learning, 24(1), 143-159.

Penuel, W.R., Roschelle, J. \& Shechtman, N. (2007). Designing formative assessment software with teachers: an analysis of the co-design process', Research and Practice in Technology Enhanced Learning, 2(2), 51-74.

Prensky, M. (2001a). Digital natives, digital immigrants. Part 1. On the Horizon, 9( 5), 1-6.

Prensky, M. (2001b). Digital game-based learning, NY: McGraw-Hill.

Rock, D., \& Brumbaugh, D. K. (2013). Teaching secondary mathematics (Fourth Edition). New York, NY: Routletge.

Samaniego, A. H. F., \& Barrera, S. V. (1999) Brousseau in action: Didactical situation for learning how to graph functions. The Fourth Asian Technology Conference in Mathematics. Guangzhou, China. Retrieved February 03, 2017, from http://www.eric.ed.gov/PDFS/ED451036.pdf

Selman, E., \& Tapan-Broutin, M. S. (2018). Teaching Symmetry in the Light of Didactic Situations. Journal of Education and Training Studies, 6(11), 139-146.

Sqire, K. (2005). Changing the game: What happens when video games enter the classroom? Innovate: Journal of Online Education, 1(6), Retrived from https://nsuworks.nova.edu/innovate/vol1/iss6/5

Taşdemir, Ş. \& Şüyun, S. B. (2016). Bilgisayar oyun tasarımı ve eğitsellik kazandırılmasına yönelik bir yaklaşım. Journal of Selcuk-Technic, 15(2), 113-124.

Usiskin, Z., Peressini, A., Marchisotto, E. A., \& Stanley, D. (2003). Mathematics for high school teachers: An advanced perspective. New Jersey: Prentice Hall

Van de Walle, J. A., Karp, K. S., \& Bay-Williams, J. M. (2007). Elementary and middle school mathematics: Teaching developmentally. New Jersey: Pearson Education.

Warfield, V., M. (2014). Invitationto didactique. New York: Springer.

Yıldırım, İ., \& Demir, S. (2014). Oyunlaştırma ve eğitim. International Journal of Human Sciences, 11(1), 655-670. doi:10.14687/ijhs.v11i1.2765

Yıldırım, A. \& Şimşek, H. (2016). Sosyal bilimlerde nitel araştırma yöntemleri (10. Baskı). Ankara: Seçkin Yayıncılık.

JCER's Publication Ethics and Publication Malpractice Statement are based, in large part, on the guidelines and standards developed by the Committee on Publication Ethics (COPE). This article is available under Creative Commons CC-BY 4.0 license (https://creativecommons.org/licenses/by/4.0/) 